\title{
New genetic sources of resistance in the genus Phaseolus to individual and combined aluminium toxicity and progressive soil drying stresses
}

\author{
Louis Butare $\cdot$ Idupulapati Rao • \\ Philippe Lepoivre · José Polania • César Cajiao • \\ Juan Cuasquer $\cdot$ Stephen Beebe
}

Received: 18 February 2011 / Accepted: 23 May 2011/Published online: 12 June 2011

(C) Springer Science+Business Media B.V. 2011

\begin{abstract}
Bean species and genotypes show wide phenotypic variability in relation to aluminium (Al) resistance and progressive soil drying. The objective of this study was to identify and characterize sources of resistance to Al toxicity and progressive soil drying among six genotypes of common bean (Phaseolus vulgaris), four of runner bean (P. coccineus), and one of tepary bean ( $P$. acutifolius), using hydroponic and soil cylinder screening methods. One experiment on hydroponic screening of $\mathrm{Al}$ resistance was carried out using a basal nutrient solution with and without $20 \mu \mathrm{M}$ Al. Two experiments were carried out using two oxisols in $80 \mathrm{~cm}$ long soil cylinders with high $\mathrm{Al}(\mathrm{HAl})$ and low $\mathrm{Al}$ (LAl) saturation treatments. The three experiments showed an average of 36.9-53.5\% inhibition of root growth with HAl compared with LAl treatments. Differences in root development and distribution were observed
\end{abstract}

L. Butare · I. Rao · J. Polania - C. Cajiao ·

J. Cuasquer $\cdot$ S. Beebe $(\square)$

Centro Internacional de Agricultura Tropical (CIAT),

A. A. 6713, Cali, Colombia

e-mail: s.beebe@cgiar.org

L. Butare · P. Lepoivre

Université de Liège (ULg), Gembloux Agro-Bio Tech,

Unité de Phytopathologie, Passage des Déportés, 2,

5030 Gembloux, Belgium

\section{Butare}

Institut des Sciences Agronomiques du Rwanda (ISAR), 47 Rue Député Kamunzizi, BP 5016 Kigali, Rwanda among genotypes and species. Two accessions of $P$. coccineus (G35346-2Q, G35464-5Q) and one Andean common bean genotype (ICA Quimbaya) were outstanding in root and shoot growth in the HAl treatments. $P$. coccineus accession (G35346-3Q) was outstanding under combined stress of Al-toxic acid soil and progressive soil drying. Accessions of $P$. coccineus may represent unique sources of $\mathrm{Al}$ resistance for the improvement of common bean through interspecific crosses.

Keywords Abiotic stress - Acid soil ·

Aluminium resistance $\cdot$ Root growth .

Screening methods $\cdot$ Water stress

\begin{tabular}{|c|c|}
\hline \multicolumn{2}{|c|}{ Abbreviations } \\
\hline HAl & High aluminium soil saturation \\
\hline LA & Leaf area \\
\hline LAl & Low aluminium soil saturation \\
\hline MRD & Mean root diameter \\
\hline NRT & Number of root tips \\
\hline RDW & Root dry weight \\
\hline REGWQ & $\begin{array}{l}\text { Ryan-Einot-Gabriel-Welsh Multiple } \\
\text { Test }\end{array}$ \\
\hline $\mathrm{R}: \mathrm{S}$ & Root to shoot \\
\hline SDW & Shoot dry weight \\
\hline SRL & Specific root length \\
\hline TPRL48h & $\begin{array}{l}\text { Tap root length at } 48 \mathrm{~h} \text { of exposure to } \\
\text { with and without aluminium in solution }\end{array}$ \\
\hline TPRL120h & $\begin{array}{l}\text { Tap root length at } 120 \mathrm{~h} \text { of exposure to } \\
\text { with and without aluminium in solution }\end{array}$ \\
\hline
\end{tabular}


TRER

Tap root elongation rate

TRL Total root length

VRD29d

VRD33d

WS

WW
Visual rooting depth at 29 days

Visual rooting depth at 33 days

Water stress

Well watered

\section{Introduction}

Common bean (Phaseolus vulgaris L.) is one of the most important grain legumes for direct human consumption in the world. The crop is mainly produced on small-scale farms in developing countries in Latin America and Africa where both biotic and abiotic stress factors limit production. About $60 \%$ of the bean growing area is affected by drought while about $40 \%$ of the bean growing area is affected by aluminium $(\mathrm{Al})$ toxicity, resulting in yield reductions from 30 to $60 \%$ (Wortmann et al. 1998; Thung and Rao 1999). Abiotic stress resistance is by its nature more complex physiologically, typically subject to large environmental effects and has been less well studied than biotic stress resistance in common bean (Rao 2001).

Aluminium is one of the most abundant minerals in the soil, comprising approximately $7 \%$ of soil mass. At neutral or weakly acidic $\mathrm{pH}$, it exists in insoluble forms of alumino-silicate or oxide. However, in acidic soils, it is solubilised into a phytotoxic form. Toxic Al levels damage roots, restrict plant size, and lower yield in most crops (Villagarcia et al. 2001). Aluminium toxicity results in inhibition of root elongation (Mossor-Pietraszewska 2001; Horst et al. 2010). The toxic effects of $\mathrm{Al}$ in soil can be overcome by adding appropriate soil amendments such as lime (Pandey et al. 1994; Villagarcia et al. 2001). However, lime application usually must be repeated over several years and is not affordable to most smallholders in developing countries that grow beans. Developing bean genotypes tolerant to acid soil conditions is an ecologically friendly, energyconserving, and economical solution for resourcepoor farmers in the tropics (Rangel et al. 2005).

Genotypic differences in seed yield of common bean germplasm accessions and breeding lines have been observed in field screening on Al-toxic acid soils that were amended with or without lime $(65 \%$

Al saturation) (Rao 2001; Rao et al. 2004). These genotypic differences in seed yield could be related to differences in resistance to $\mathrm{Al}$, and acquisition and utilization of nutrients for transport of photoassimilates to developing seeds. Significant genotypic differences in $\mathrm{Al}$ resistance in common bean were reported based on Al-inhibited root elongation in nutrient solution (Foy 1988; Massot et al. 1999; Rangel et al. 2005, 2007; Manrique et al. 2006). Differential genotypic response to $\mathrm{Al}$ stress contributes to identification of new sources of $\mathrm{Al}$ resistance as well as improved understanding of mechanisms of Al resistance in common bean (Rangel et al. 2005, 2007, 2009, 2010; Blair et al. 2009; López-Marín et al. 2009). Resistance to $\mathrm{Al}$ in common bean is attributed to the release of citrate by the root apex (Rangel et al. 2010) and the expression of a citrate transporter MATE (multidrug and toxin extrusion family protein) gene is crucial for citrate exudation (Eticha et al. 2010). Although the MATE gene expression was a prerequisite for citrate exudation and $\mathrm{Al}$ resistance, genotypic difference in $\mathrm{Al}$ resistance in common bean was mainly dependent on the capacity to sustain the synthesis of citrate for maintaining the cytosolic citrate pool that enables exudation (Rangel et al. 2010; Eticha et al. 2010). The initial Al-induced inhibition of root elongation in both Al-resistant (ICA Quimbaya) and Al-sensitive (VAX 1) genotypes was correlated with the expression of the ACCO (1-aminocyclopropane-1carboxylic acid oxidase) gene (Eticha et al. 2010).

Improving $\mathrm{Al}$ resistance in plants has been limited by inadequate screening methodologies (Villagarcia et al. 2001). Screening for Al resistance based on field data would be strengthened by complimentary evaluation of specific phenotypic and physiological traits. Hydroponic systems have been used with success in evaluation of $\mathrm{Al}$ resistance for many crops and are an attractive alternative. They allow evaluation of a large number of genotypes quickly and have been used to identify parental stock for soybean breeding (Bianchi-Hall et al. 1998; Campbell and Carter 1990; Carter and Rufty 1993; Spehar 1994; Bianchi-Hall et al. 2000; Silva et al. 2001). Common bean and soybean both pertain to the tribe Phaseoleae, much more closely related to each other than they are to Lotus, Medicago, or other grain legumes such as lentils or chickpeas (Choi et al. 2004). This opens the possibility of common genes and/or 
mechanisms between the species, and suggests that the application of methods used in soybean might serve to discriminate genetic differences in common bean as well. Hydroponic systems for evaluation of genetic materials provide a strict control of nutrient availability and are widely used in genetic studies. To complement the hydroponic screening system, researchers at CIAT developed a greenhouse screening method using vertical soil cylinders with high $\mathrm{Al}$ (HAl) saturation to quantify genotypic differences in root development and distribution in Al-toxic soil conditions (CIAT 2008). Soil-based systems offer a medium that is more similar to field conditions. This methodology also permits characterization of the root system, in terms of rooting depth and branching of fine roots in a soil with known bulk density.

Drought is a major abiotic stress in many parts of the world (Johansen et al. 1994). There is an urgent need for developing high yielding drought resistant cultivars that use water efficiently, reduce dependence on irrigation water and associated production costs, increase and stabilize yield in drought-prone environments, and increase profit margins for producers (Muñoz-Perea et al. 2006). Selection for drought resistance based on yield alone may not recover all specific physiological attributes as these might be expressed differentially under distinct conditions (Subbarao et al. 1995). Rooting pattern, especially greater root length in lower soil strata, is an important drought resistance mechanism for common bean (Sponchiado et al. 1989). Drought resistant bean genotypes could extend their roots to $1.2 \mathrm{~m}$ depth in drought environments, whereas the sensitive genotypes could not extend their roots beyond $0.8 \mathrm{~m}$; and these differences in rooting depths were reflected in overall shoot growth and yield (White and Castillo 1988). Root systems show considerable architectural variation among species, among genotypes of given species, and even with different parts of a single root system (Lynch 1995). Wild relatives in many legumes possess deep rooting capability that could be transferred to cultivated legumes. A number of Phaseolus species, such as $P$. acutifolius, $P$. retensis, and $P$. coccineus, have deep and/or tuberous primary root attributes (Singh and White 1988).

Understanding the genetic and physiological mechanisms by which plants cope with changes in environmental conditions is critical for creating efficient strategies to develop stress-resistant cultivars for sustainable production systems (Rao 2001). Abiotic stress factors often co-occur in farmers' fields. Roots that are stunted by Al toxicity are inefficient in absorbing both nutrients and water (Mossor-Pietraszewska 2001). Al-resistant plants may be more drought tolerant and require lower inputs of lime and $\mathrm{P}$ fertilizer than less resistant genotypes (Little 1988). Yang et al. (2010) characterized the combined Al toxicity and drought stress on root growth, with special emphasis on $\mathrm{Al} /$ drought interaction in the root apex of common bean. Using polyethylene glycol (PEG) to simulate osmotic stress (OS) or drought stress, they found that OS enhances $\mathrm{Al}$ resistance by inhibiting $\mathrm{Al}$ accumulation in the root apices of the Al-sensitive genotype (VAX 1). This alleviation of $\mathrm{Al}$ toxicity was found to be related to the alteration of cell wall porosity resulting from PEG-induced dehydration of the root apoplast.

Improving resistance to two complex stresses such as $\mathrm{Al}$ toxicity and water stress (WS) in common bean requires identifying new sources of resistance among $P$. vulgaris accessions and in sister species including $P$. coccineus and $P$. acutifolius. $P$. coccineus is placed within the secondary gene pool and can be crossed readily with common bean. $P$. acutifolius is considered to form part of the tertiary gene pool, but can also be crossed to common bean using embryo rescue. The objective of this work was to identify potential parents based on phenotypic differences among bean genotypes in root development and root distribution under individual and combined stress factors of $\mathrm{HAl}$ toxicity and progressive soil drying.

\section{Materials and methods}

Three greenhouse trials were conducted at CIAT headquarters in Palmira (Lat. $3^{\circ} 29^{\prime} \mathrm{N}$; Long. $76^{\circ} 21^{\prime} \mathrm{W}$, Altitude $965 \mathrm{~m}$ ) using hydroponic and soil cylinder systems. For purposes of these studies, "Al resistance" refers to the response of a genotype to toxic $\mathrm{Al}$ in the hydroponic system, and tolerance to Al-toxic acid soil conditions refers to tolerance to $\mathrm{HAl}$ saturation in acid soil together with low availability of nutrients. A single hydroponic screening (Trial 1) employed a low ionic strength nutrient solution to evaluate root traits of seedlings grown with or without $20 \mu \mathrm{M} \mathrm{Al}$ in a basal nutrient solution (Rangel et al. 2005, 2007). One soil cylinder experiment (Trial 2) compared plant response 
in two oxisols with $\mathrm{HAl}$ and low $\mathrm{Al}(\mathrm{LAl})$ saturation. A second soil cylinder experiment (Trial 3) was conducted to evaluate plant response to individual and combined stress factors of acid soil (HAl and LAl saturation) and two levels of soil moisture (well watered (WW) and water stress (WS) induced by progressive soil drying) in a factorial design.

\section{Plant materials}

Eleven bean genotypes were selected for the study from our previous work (CIAT 2005; S. Beebe, unpublished data), including four runner bean (P. coccineus) accessions (G35066-1Q, G35346-2Q, G35346-3Q and G35464-5Q); six common bean genotypes including two large seeded beans of the Andean gene pool (ICA Quimbaya and IJR, indeterminate Jamaica red) and four lines of the Mesoamerican gene pool (VAX1, VAX3, VAX6, SER16); and one tepary bean (P. acutifolius) accession (G40159). The P. coccineus accessions had been identified in a field screening of 155 entries of $P$. coccineus and $P$. polyanthus in an $\mathrm{Al}$ toxic field site in Santander of Quilichao, Colombia, based on shoot vigor (S. Beebe, unpublished results). P. acutifolius is a drought resistant desert species and one of its accessions, G40159 had been identified as especially drought resistant (Rao et al. 2007). The VAX lines had been selected for common bacterial blight resistance in Santander of Quilichao during their development, and VAX1 had expressed good shoot vigor in $\mathrm{Al}$ toxic soils. These plant materials were evaluated for their phenotypic differences under individual and combined stresses of $\mathrm{Al}$ and drought. For the hydroponic experiment, germinated seeds were transferred to small pots containing sterile sand for root development and were carefully removed from the sand after 3 days. Seedlings with uniform vigour and tap root length were chosen for evaluation in hydroponic system. For the two soil cylinder experiments, seeds were surface sterilized with sodium hypochlorite ( $1 \%$ for $5 \mathrm{~min}$ ) and washed with abundant deionised water. Seeds were germinated on filter paper for 2-3 days before planting in soil tubes.

Evaluation for $\mathrm{Al}$ resistance using hydroponic system

The hydroponic experiment (Trial 1) was conducted during November and December 2007. Plants were grown in a greenhouse with an average temperature of $31.1 / 22.3^{\circ} \mathrm{C}$ (day/night), a relative humidity of $48.0 / 67.3 \%$ (day/night), and with a maximum photosynthetic active radiation of $1,100 \mu \mathrm{mol} \mathrm{m} \mathrm{m}^{-2} \mathrm{~s}^{-1}$ photon flux density at noon. Seedlings with uniform root length $(5-7 \mathrm{~cm})$ were selected for evaluation with nutrient solution composed with $5 \mathrm{mM} \mathrm{CaCl}_{2}$, $0.5 \mathrm{mM} \mathrm{KCl}$ and $8 \mu \mathrm{M} \mathrm{H}_{3} \mathrm{BO}_{3}$ at $\mathrm{pH} 4.5$, with or without $20 \mu \mathrm{M} \mathrm{AlCl}_{3}$ (Rangel et al. 2007; LópezMarín et al. 2009). Mononuclear $\mathrm{Al}$ ( $\left.\mathrm{Al}_{\text {mono }}\right)$ concentration was measured colorimetrically using aluminon or pyrocatechol violet method according to Kerven et al. (1989). Aluminium treatment of $20 \mu \mathrm{M}$ resulted in $16 \pm 2 \mu \mathrm{M} \mathrm{Al}_{\text {mono }}$ after $24 \mathrm{~h}$. Twenty liter plastic tanks were filled with 161 of nutrient solution. Each seedling was placed in an individual compartment in a tray floating on the solution, and the nutrient solution was permanently aerated with a compressor during the evaluation. Acclimation to low $\mathrm{pH}$ before applying $\mathrm{Al}$ treatment was made by adjusting the solution $\mathrm{pH}$ to 5.5 for $0 \mathrm{~h}$, followed by $\mathrm{pH} 4.9$ for $18 \mathrm{~h}$ and lastly by $\mathrm{pH} 4.5$ for $24 \mathrm{~h}$ (Rangel et al. 2007). Nutrient solutions were renewed every third day. Plants with the same root length were distributed in pairs in each treatment after measuring the length of tap root with a ruler. The experimental design was a randomized complete block with five to ten replications.

Root morphological attributes were evaluated. Tap root length (TPRL) at $48 \mathrm{~h}$ (TPRL48h) and at $120 \mathrm{~h}$ (TPRL120h) was recorded. Tap root elongation rate (TRER) was determined at $48 \mathrm{~h}$ (TRER48h) and after $120 \mathrm{~h}$ (TRER120h) with and without $\mathrm{Al}$ stress based on the initial measurement of tap root length. TRER was defined as the difference between the initial and final tap root length during the treatment period; and Al-induced inhibition of TRER was calculated according to Rangel et al. (2005):

Inhibition of root elongation $(\%)$
$\quad=\left[\left(\right.\right.$ TRER $\left.\left._{\text {control }}-\operatorname{TRER}_{\mathrm{Al}}\right) / \mathrm{TRER}_{\text {control }}\right] \times 100$

At harvest, roots were separated from the rest of the plants, saved in plastic bags and refrigerated at $4^{\circ} \mathrm{C}$ while proceeding to analyze images using a flatbed colour scanner, Epson Expression1680 Scanner. Differences in root morphological attributes among genotypes including total root length (TRL), mean root diameter (MRD), and number of root tips (NRT) were analyzed using WinRhizo ${ }^{\circledR}$ software program. 
Specific root length (SRL, root length per unit dry weight) was calculated, and the root dry weight (RDW) was determined by drying roots at $65^{\circ} \mathrm{C}$ in an oven for $48 \mathrm{~h}$.

Evaluation for individual and combined stress in soil

Two soil cylinder experiments were carried out, each arranged as three randomized complete blocks. The first soil cylinder experiment (Trial 2) compared plant response in Oxisols with $\mathrm{LAl}$ and $\mathrm{HAl}$ saturation and was conducted during June-July 2007 in a greenhouse in Palmira (CIAT/Colombia) with an average temperature of $29.4 / 23.1^{\circ} \mathrm{C}$ (day/night), relative humidity of $57.2 / 79.4 \%$ (day/night), and maximum photosynthetic active radiation of $1,100 \mu \mathrm{mol} \mathrm{m} \mathrm{m}^{-2} \mathrm{~s}^{-1}$ photon flux density at noon.

Stress of Al-toxic acid soil was simulated using soils collected from Santander de Quilichao, Cauca Department $\left(3^{\circ} 06^{\prime} \mathrm{N}\right.$ lat., $76^{\circ} 31^{\prime} \mathrm{W}$ long; $990 \mathrm{~m}$ altitude), Colombia. Soil used in the $\mathrm{Al}$ stress treatment ( $\mathrm{HAl}$ ) was characterized by a $\mathrm{pH}$ of 4.11 and $76 \% \mathrm{Al}$ soil saturation $(0-10 \mathrm{~cm})$ for top-soil (top $10 \mathrm{~cm}$ of the cylinder) and $83 \% \mathrm{Al}$ saturation for subsoil (10-75 cm) with $\mathrm{pH} 4.14$ (Table 1). This treatment did not receive any additional fertilizer application to simulate HAl with low nutrient availability soil conditions that are typical of Al-toxic acid soils. Root and shoot growth of bean genotypes under this treatment was visually (based on symptoms) restricted by both Al-toxicity and low availability of P. Soil used for LAl treatment was characterized by a $\mathrm{pH}$ of 4.45 and $28 \% \mathrm{Al}$ saturation $(0-10 \mathrm{~cm})$ for topsoil and 58\% Al saturation for subsoil $(10-75 \mathrm{~cm})$ with $\mathrm{pH} 4.29$.
The soil cylinders for LAl treatment were packed with Quilichao soil (described in Table 1), previously fertilized with adequate amendments $\left(\mathrm{g} \mathrm{kg}^{-1}\right.$ soil) for top soil $(0-10 \mathrm{~cm}$ ): $3.69 \mathrm{~N}$ (urea), $5.30 \mathrm{P}$ (triple superphosphate), $5.30 \mathrm{Ca}$ (triple superphosphate), $4.08 \mathrm{~K}(\mathrm{KCl}), 6.36 \mathrm{Ca}\left(\mathrm{CaCO}_{3}\right), 6.36 \mathrm{Mg}\left(\mathrm{MgCO}_{3}\right.$ or dolomite lime), $0.49 \mathrm{~S}$ (elemental sulphur), $0.09 \mathrm{Zn}$ $\left(\mathrm{ZnCl}_{2}\right), 0.11 \mathrm{CuCl}_{2} \cdot 2 \mathrm{H}_{2} \mathrm{O}, 0.01 \mathrm{~B}\left(\mathrm{H}_{3} \mathrm{BO}_{3}\right)$ and 0.01 Mo $\left(\mathrm{NaMoO}_{4} \cdot 2 \mathrm{H}_{2} \mathrm{O}\right)$; and for subsoil $(10-75 \mathrm{~cm})$ 14.76 N (urea), 21.2 P (triple superphosphate), 21.21 $\mathrm{Ca}$ (triple superphosphate), $16.32 \mathrm{~K}(\mathrm{KCl}), 25.45 \mathrm{Ca}$ $\left(\mathrm{CaCO}_{3}\right), 25.45 \mathrm{Mg}\left(\mathrm{MgCO}_{3}\right.$ or dolomite lime $), 1.97$ $\mathrm{S}$ (elemental sulphur), $0.36 \mathrm{Zn} \quad\left(\mathrm{ZnCl}_{2}\right), 0.46$ $\mathrm{CuCl}_{2} \cdot 2 \mathrm{H}_{2} \mathrm{O}, 0.05 \mathrm{~B}\left(\mathrm{H}_{3} \mathrm{BO}_{3}\right)$ and $0.02 \mathrm{Mo}(\mathrm{Na}-$ $\mathrm{MoO}_{4} \cdot 2 \mathrm{H}_{2} \mathrm{O}$ ). This level of fertilizer application was designed to provide adequate supply of nutrients, and it did not affect $\mathrm{Al}$ saturation and $\mathrm{pH}$ of the amended soil. The polyethylene cylinders were inserted into PVC pipes and were maintained at $80 \%$ field capacity by weighing each cylinder every 3 days and applying water to the soil at the top (Polanía et al. 2009).

Shoot and root attributes were evaluated on plants in soil tubes. Total chlorophyll content (SPAD) was measured every week using SPAD-502 Chlorophyll meter (Minolta camera Co., Ltd, Japan). Visual rooting depth (VRD) was determined at 29 days after planting. At the time of harvest (29 days after planting), leaf area (LA) was determined by scanning leaves of each genotype using a LI-3100 Area meter (LI-COR Biosciences). Shoot dry weight (SDW) was measured after drying leaves, stems and pods in an oven at $70^{\circ} \mathrm{C}$ for $72 \mathrm{~h}$. Each soil cylinder was sliced into six layers representing different soil depths (0-5, 5-10, 10-20, 20-40, 40-60, 60-75 cm), soil and roots were collected, and roots washed and cleaned to separate living plant roots from organic debris before

Table 1 Chemical characteristics of two oxisols with HAl or LAl saturation from Santander of Quilichao used for evaluating acid soil tolerance

\begin{tabular}{|c|c|c|c|c|c|c|c|c|c|}
\hline $\begin{array}{l}\mathrm{Al} \\
\text { saturation }\end{array}$ & $\begin{array}{l}\text { Soil } \\
\text { depth } \\
(\mathrm{cm})\end{array}$ & $\mathrm{pH}$ & $\begin{array}{l}\mathrm{Al} \\
\left(\mathrm{cmol} \mathrm{kg}{ }^{-1} \text { soil }\right)\end{array}$ & $\begin{array}{l}\mathrm{Ca} \\
\left(\mathrm{cmol} \mathrm{kg}{ }^{-1} \text { soil }\right)\end{array}$ & $\begin{array}{l}\mathrm{Mg} \\
\left(\mathrm{cmol} \mathrm{kg}^{-1} \text { soil }\right)\end{array}$ & $\begin{array}{l}\mathrm{K} \\
\left(\mathrm{cmol} \mathrm{kg}{ }^{-1} \text { soil }\right)\end{array}$ & $\begin{array}{l}\text { Al } \\
\text { sat. } \\
(\%)\end{array}$ & $\begin{array}{l}\text { SOM } \\
(\%)\end{array}$ & $\begin{array}{l}\text { Available } \\
\mathrm{P}\left(\mathrm{mg} \mathrm{kg}^{-1}\right)\end{array}$ \\
\hline High & $0-10$ & 4.11 & 4.60 & 0.94 & 0.30 & 0.18 & 76 & 5.96 & 8.80 \\
\hline High & $10-20$ & 4.14 & 4.40 & 0.69 & 0.16 & 0.07 & 83 & 4.94 & 3.30 \\
\hline Low & $0-10$ & 4.45 & 1.65 & 3.32 & 0.89 & 0.26 & 28 & 5.38 & 9.70 \\
\hline Low & $10-20$ & 4.29 & 3.02 & 1.63 & 0.25 & 0.28 & 58 & 4.56 & 4.30 \\
\hline
\end{tabular}

SOM Soil organic matter 
scanning. Root length and biomass distribution were determined for each profile, but cutting of soil cylinders at different depths did not permit measuring NRT. Differences in distribution of root length and root biomass within soil cylinder among genotypes were estimated by Gale and Grigal (1987) asymptotic equation:

$\mathrm{Y}=1-\beta^{\mathrm{d}}$

where $\mathrm{Y}$ is the fraction of root length/biomass accumulated from the soil surface to depth $\mathrm{d}(\mathrm{cm})$, and $\beta$ is a parameter that describes the shape of the cumulative distribution with depth. Higher $\beta$ values (closer to 1) indicate a greater proportion of root length/biomass deeper in the soil profile. Lower $\beta$ values (e.g. $\beta=0.920$ ) imply a greater proportion of root length/biomass nearer to the soil surface.

In a second soil cylinder trial (Trial 3), individual and combined stress of $\mathrm{Al}$ and progressive soil drying were evaluated in September 2008 under greenhouse conditions at an average temperature of $30.7 / 23.3^{\circ} \mathrm{C}$ (day/night), a relative humidity of $49.0 / 68.3 \%$ (day/ night), and at an average photosynthetic photon flux density of $820 \mu \mathrm{mol} \mathrm{m} \mathrm{m}^{-2} \mathrm{~s}^{-1}$ during the day. Plants were grown in transparent tubes inserted in PVC pipes as previously described for $\mathrm{Al}$ screening with the same soil type from Santander of Quilichao. The LAl saturation treatment was fertilized with adequate supply of nutrients as described above for top soil and subsoil. The experimental design was a randomized complete block with three repetitions and with two levels of Al saturation in soil (high and low) and two levels of water supply (WW and WS due to progressive soil drying) in a factorial design. Cylinders of genotype-soil-moisture combinations were randomized within each block. Each cylinder was packed with two types of soil (top-soil and sub-soil); and maintained at $80 \%$ of field capacity by weighing every 3 days $(4,780 \mathrm{~g}$ for HAl saturation treatment cylinders and 4,910 $\mathrm{g}$ for the low saturation). WS was imposed to simulate progressive soil drying after 10 days of initial growth while for the WW treatment, water was applied to the top of cylinders to maintain them at $80 \%$ of field capacity (Polanía et al. 2009). At harvest, shoots and roots of 33 day-old plants (23 days without water application in the WS treatment) were separated, and LA measured by scanning leaves. Shoot biomass was determined after drying leaves and stems in an oven. Roots were processed in the same way as for previous soil cylinder trial (Trial 2) with individual stress treatment of Al-toxic acid soil alone and the same parameters were determined.

Statistical analysis

Analysis of variance was performed by the ANOVA statistical procedure of SAS (SAS 9.1, 2002-2003; SAS institute Inc.; SunOS 5.9 platform). The means were compared using Ryan-Einot-Gabriel-Welsh (REGWQ) Multiple Test. This test controls the type I experiment-wise error rate. Means for each dependent variable were grouped, and means with the same letter are not significantly different $(P<0.05$ level). Differences between genotypes were analyzed with the least significant difference (LSD). Correlation coefficients were calculated (PROC CORR) for all pairs of genotypic means across all replications with each treatment and for all three experiments. Regression analysis was carried with the PROC REG procedure.

\section{Results and discussion}

The response of root attributes (TRL, MRD, SRL, VRD) to Al stress was used to assess resistance of beans to Al toxicity and Al toxic acid soil. Variation among the 11 genotypes was found in this study using both hydroponic (Tables 2, 3) and soil cylinder (Tables 4, 5, 6, 7) screening systems. Relationships between traits were considered based on expectations of which combinations of traits would confer a favourable reaction to $\mathrm{Al}$ toxicity. High variability in root attributes was observed between genotypes except for TPRL at $48 \mathrm{~h}$ of treatment (TPRL48h) with $20 \mu \mathrm{M} \mathrm{Al}$ in hydroponic system. Since $P$. coccineus accessions did not show any difference in the hydroponic system between treatments with and without $\mathrm{Al}$ in solution for $48 \mathrm{~h}$, the exposure time was extended to $120 \mathrm{~h}$ where significant genotypic variation $(P<0.001)$ in $\mathrm{Al}$ resistance was observed.

Evaluation of $\mathrm{Al}$ resistance in hydroponic system

Al stress in hydroponic screening (Trial 1) affected root growth characteristics of all 11 genotypes tested. Variation in response to $\mathrm{Al}$ stress $(20 \mu \mathrm{M} \mathrm{Al})$ among 


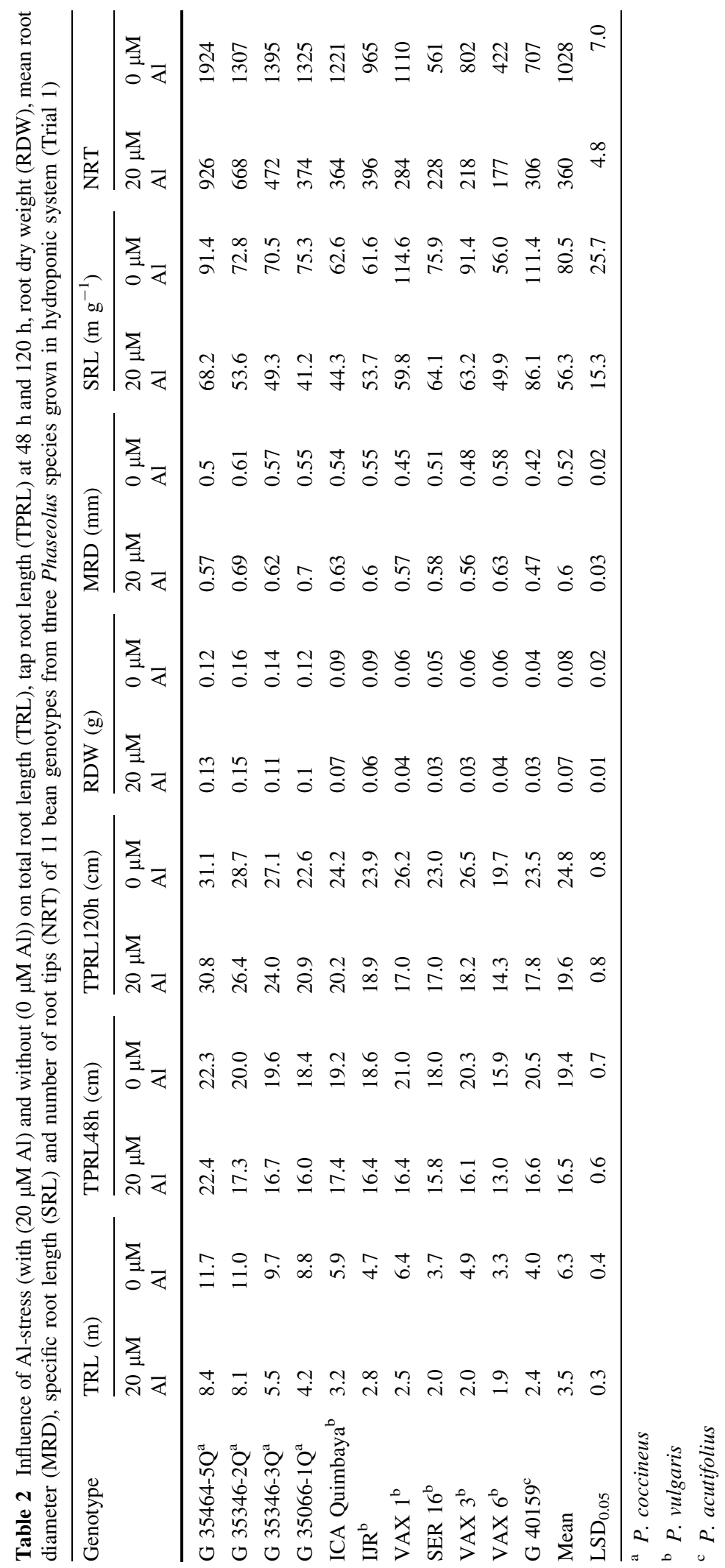


genotypes was found for TRL, TPRL48h, TPRL120h, RDW, MRD, SRL and NRT (Table 2). Three $P$. coccineus accessions (G35464-5Q, G35346-2Q, G35346-3Q) were highly resistant to $\mathrm{Al}$, whereas three Mesoamerican common bean genotypes (VAX6, VAX3, SER16) were more sensitive. Genotype $\times$ treatment (Level of $\mathrm{Al}$ ) interaction were found for SRL, NRT, MRD and TRL (Table 3). TRL was highly correlated with TPRL48h $\left(r=0.77^{* *}\right)$, with TPRL120h $(r=0.92 * * *)$, with RDW ( $\left.r=0.91^{* * *}\right)$, and with NRT ( $\left.r=0.96^{* * *}\right)$. This suggests that the tap root response to Al toxicity (TPRL5d) reflects the reaction of the rest of the root system. In contrast López-Marín et al. (2009) found that while bean genotype G19833 showed a higher TRER than DOR364 in both control and Al treatment solutions, differences in TRL between the two genotypes were less notable.

Correlation was also found between TPRL48h and NRT $\left(r=0.78^{* *}\right)$, and between TPRL48h and TPRL120h $(r=0.74 * *) \quad$ (Table 3). This latter correlation was perhaps lower than expected, considering that it reflects measurements of the same trait on the same plants over a $72 \mathrm{~h}$ period. Perhaps different plant responses were being expressed over this period, as noted by Rangel et al. $(2007,2010)$ in other trials.

TRER can be monitored easily and is assumed to be an indicator of $\mathrm{Al}$ resistance. $\mathrm{Al}$ strongly affected TRER with means varying from 0.15 to $1.0 \mathrm{~mm} \mathrm{~h}^{-1}$. TRER of three P. coccineus accessions (G35464-5Q, G35346-2Q and G35346-3Q) and ICA Quimbaya (an Andean common bean) were high $\left(>0.6 \mathrm{~mm} \mathrm{~h}^{-1}\right)$ compared to other genotypes (Fig. 1A). The major $\mathrm{Al}$ toxicity symptom observed in plants is inhibition of root elongation rate calculated from the comparison of root elongation rate with and without toxic $\mathrm{Al}$ (Marschner 1991; Ryan et al. 1993; Delhaize and Ryan 1995). TRER was inhibited by $21.3-60.7 \%$, with an average of $42.7 \%$. Three genotypes (VAX3, VAX1, G35066-1Q) were sensitive to Al with over 50\%; six genotypes including SER16, IJR, G35346-

Table 3 Correlation coefficients and mean squares for total root length (TRL), tap root length (TPRL) at $48 \mathrm{~h}$ and $120 \mathrm{~h}$, root dry weight (RDW), mean root diameter (MRD), specific

root length (SRL), and number of root tips (NRT) of 11 bean genotypes grown under hydroponic system with two level of $\mathrm{Al}$ $(20 \mu \mathrm{M} \mathrm{Al}$ and $0 \mu \mathrm{M} \mathrm{Al})($ Trial 1)

\begin{tabular}{|c|c|c|c|c|c|c|c|c|}
\hline Traits/source & Al level/DF & TRL & TPRL48h & TPRL120h & RDW & MRD & SRL & NRT \\
\hline \multirow[t]{2}{*}{ TRL } & 0 & 1 & & & & & & \\
\hline & 20 & 1 & & & & & & \\
\hline \multirow[t]{2}{*}{ TPRL48h } & 0 & $0.55(\mathrm{~ns})$ & 1 & & & & & \\
\hline & 20 & $0.77 * *$ & 1 & & & & & \\
\hline \multirow[t]{2}{*}{ TPRL120h } & 0 & $0.78 * *$ & $0.74 * *$ & 1 & & & & \\
\hline & 20 & $0.92 * * *$ & $0.74 * *$ & 1 & & & & \\
\hline \multirow[t]{2}{*}{ RDW } & 0 & $0.85 * * *$ & $0.13(\mathrm{~ns})$ & $0.58(\mathrm{~ns})$ & 1 & & & \\
\hline & 20 & $0.91 * * *$ & $0.59(\mathrm{~ns})$ & $0.83 * *$ & 1 & & & \\
\hline \multirow[t]{2}{*}{ MRD } & 0 & $0.14(\mathrm{~ns})$ & $-0.59(\mathrm{~ns})$ & $-0.04(\mathrm{~ns})$ & $0.61 *$ & 1 & & \\
\hline & 20 & $0.29(\mathrm{~ns})$ & $-0.13(\mathrm{~ns})$ & $0.24(\mathrm{~ns})$ & 0.57 (ns) & 1 & & \\
\hline \multirow[t]{2}{*}{ SRL } & 0 & 0.17 (ns) & $0.72 *$ & $0.26(\mathrm{~ns})$ & $-0.34(\mathrm{~ns})$ & $-0.84 * * *$ & 1 & \\
\hline & 20 & $-0.23(\mathrm{~ns})$ & $0.07(\mathrm{~ns})$ & $-0.20(\mathrm{~ns})$ & $-0.46(\mathrm{~ns})$ & $-0.87 * * *$ & 1 & \\
\hline \multirow[t]{2}{*}{ NRT } & 0 & $0.95 * * *$ & 0.43 (ns) & $0.66^{*}$ & $0.86^{* * * *}$ & $0.16(\mathrm{~ns})$ & 0.04 (ns) & 1 \\
\hline & 20 & $0.96 * * *$ & $0.78 * *$ & $0.91 * * *$ & $0.84 * * *$ & $0.20(\mathrm{~ns})$ & $-0.11(\mathrm{~ns})$ & 1 \\
\hline Level of $\mathrm{Al}$ & 1 & $12.34 * * *$ & $4.54 *$ & $10.93 * * *$ & $0.0062 * * *$ & $0.0494 * * *$ & $11894 * * *$ & $5158 * * *$ \\
\hline Rep. (Al level) & 4 & $0.099(\mathrm{~ns})$ & $0.46(\mathrm{~ns})$ & $0.68(\mathrm{~ns})$ & $0.0002(\mathrm{~ns})$ & $0.0008(\mathrm{~ns})$ & $518.5(\mathrm{~ns})$ & 34.97 (ns) \\
\hline Genotype & 10 & $4.93 * * *$ & $0.86^{*}$ & $2.33 * * *$ & $0.0157 * * *$ & $0.0184 * * *$ & $5894 * * *$ & $525.5 * * *$ \\
\hline Gen. $\times$ Al level & 10 & $2.23 *$ & $0.1(\mathrm{~ns})$ & $0.45(\mathrm{~ns})$ & $0.0001(\mathrm{~ns})$ & $0.0015 *$ & $1713 * * *$ & $73.77 * *$ \\
\hline Error & 236 & 0.12 & 0.37 & 0.53 & 0.0002 & 0.0007 & 377.5 & 30.3 \\
\hline
\end{tabular}

$n s$ Non significant

Statistical significance at the $* 0.5, * * 0.01$, and $* * * 0.001$ probability levels, respectively 
Table 4 Influence of acid soil stress ( $H A l$ high aluminium saturation, $L A l$ low aluminium saturation) on total root length (TRL), mean root diameter (MRD), specific root length (SRL) and VRD at 29 days (VRD29d) for 29 days-old plants of 11 bean genotypes from three Phaseolus species grown in soil cylinders under "WW conditions" (Trial 2)

\begin{tabular}{|c|c|c|c|c|c|c|c|c|}
\hline \multirow[t]{2}{*}{ Genotype } & \multicolumn{2}{|c|}{ TRL (m) } & \multicolumn{2}{|c|}{ MRD (mm) } & \multicolumn{2}{|c|}{ VRD29d $(\mathrm{cm})$} & \multicolumn{2}{|c|}{$\operatorname{SRL}\left(\mathrm{m} \mathrm{g}^{-1}\right)$} \\
\hline & HAl & LAl & HAl & LAl & HAl & LAl & HAl & LAl \\
\hline G $35464-5 Q^{a}$ & 40.0 & 66.1 & 0.34 & 0.33 & 68.0 & 66.7 & 96.1 & 89.8 \\
\hline G $35346-2 Q^{a}$ & 62.0 & 76.8 & 0.33 & 0.35 & 74.3 & 71.3 & 88.8 & 88.6 \\
\hline G $35346-3 Q^{a}$ & 40.1 & 73.0 & 0.35 & 0.37 & 75.0 & 75.0 & 84.8 & 79.3 \\
\hline G $35066-1 Q^{a}$ & 24.6 & 47.1 & 0.30 & 0.29 & 57.0 & 64.3 & 65.8 & 111.8 \\
\hline I. Quimbaya ${ }^{\mathrm{b}}$ & 22.8 & 55.1 & 0.31 & 0.31 & 62.0 & 65.7 & 63.1 & 90.4 \\
\hline $\mathrm{IJR}^{\mathrm{b}}$ & 18.1 & 57.2 & 0.32 & 0.31 & 55.8 & 75.0 & 61.9 & 113.0 \\
\hline $\mathrm{VAX} 1^{\mathrm{b}}$ & 23.0 & 56.1 & 0.24 & 0.24 & 40.8 & 62.7 & 61.1 & 126.2 \\
\hline SER $16^{\mathrm{b}}$ & 15.4 & 53.1 & 0.26 & 0.28 & 37.7 & 66.3 & 71.3 & 109.5 \\
\hline $\operatorname{VAX} 3^{\mathrm{b}}$ & 15.0 & 59.5 & 0.26 & 0.27 & 45.0 & 64.7 & 67.1 & 114.9 \\
\hline $\operatorname{VAX} 6^{\mathrm{b}}$ & 19.1 & 50.0 & 0.28 & 0.27 & 55.0 & 57.0 & 71.6 & 106.5 \\
\hline $\mathrm{G} 40159^{\mathrm{c}}$ & 21.3 & 55.5 & 0.25 & 0.27 & 53.0 & 69.0 & 134.3 & 135.7 \\
\hline Mean & 27.4 & 59.0 & 0.29 & 0.30 & 56.7 & 67.1 & 78.7 & 106.0 \\
\hline $\mathrm{LSD}_{0.05}$ & 22.6 & 32.0 & 0.09 & 0.07 & 24.2 & 17.02 & 45.7 & 35.1 \\
\hline
\end{tabular}

${ }^{\text {a } P \text {. coccineus }}$

b $P$. vulgaris

c P. acutifolius

3Q, VAX6, ICA Quimbaya, and G40159 were intermediate with inhibition between 37.5 and $44.0 \%$, whereas $P$. coccineus accessions G353462Q and G35464-5Q were resistant with inhibition of 30.8 and $21.3 \%$, respectively (Fig. 1B), confirming the variability observed previously between the two bean species (CIAT 2005), and the level of $\mathrm{Al}$ resistance reported in ICA Quimbaya (Rangel et al. 2007).

Fine and extensive roots that continue to grow and that thicken less in the presence of toxic $\mathrm{Al}$ should be able to explore Al toxic soil more efficiently (Eisenstat 1992; Villagarcia et al. 2001). Genotypes grown in presence or absence of $\mathrm{Al}$ for $120 \mathrm{~h}$ also showed differential response to $\mathrm{Al}$ for the increase of MRD, ranging from 8.1 to $20.5 \%$ (Fig. 1C). VAX6, G35346-3Q, G40159, and ICA Quimbaya presented less increase of root diameter $(<9.43 \%)$. Five genotypes from different bean species and gene pools (G35464-5Q, G35346-3Q, G40159, ICA Quimbaya and VAX6) were outstanding for minimizing inhibition of TRER and increase of root diameter (Fig. 1). In contrast, $\mathrm{Al}$ sensitive line VAX1 presented inhibition of TRER and increase of MRD of 60.3 and $20.2 \%$, respectively. Similar results were found before in evaluation of $\mathrm{Al}$ resistance among 52 genotypes of common bean (CIAT 2005). Villagarcia et al. (2001) reported that number of basal roots and branching from tap root were clearly reduced by $\mathrm{Al}$ in all soybean genotypes. We found similar results for NRT (root branching) and for SRL which is affected by number of fine branches. As expected, SRL exhibited a strong negative correlation with average root diameter in the hydroponic system. However, the ranking of genotypes by SRL did not appear to correspond to ranking by other traits.

Evaluation for Al-toxic acid soil tolerance

Aluminium-toxic acid soil in Trial 2 affected all root parameters except for MRD (Tables 4, 5). Average values for $\mathrm{LAl}$ and $\mathrm{HAl}$ treatments, respectively were: TRL, 59 and $27.4 \mathrm{~m}$; MRD, 0.30 and $0.29 \mathrm{~mm}$; VRD29d, 67.1 and $56.7 \mathrm{~cm}$; and SRL, 106.0 and $78.7 \mathrm{~m} \mathrm{~g}^{-1}$. Genotypic differences were highly significant for TRL, MRD, SRL and VRD29d at 29 days. Acid soil tolerant genotypes G35346-2Q, G35346-3Q and G35464-5Q maintained good root structure in acid soil. Genotype $\times \mathrm{Al}$ level interaction was significant for SRL and VRD29d at 29 days. In 
Table 5 Correlation coefficients and mean squares for total root length (TRL), mean root diameter (MRD), specific root length (SRL), VRD at 29 days (VRD29d), leaf area (LA), shoot dry weight (SDW) and root:shoot ratio (R:S ratio) of
29 days-old plants of 11 bean genotypes evaluated under conditions of high $\mathrm{Al}$ saturation (HAl) and low $\mathrm{Al}$ saturation (LAl) in soil cylinders under "WW conditions" (Trial 2)

\begin{tabular}{|c|c|c|c|c|c|c|c|c|}
\hline Traits/source & Al level/DF & TRL & MRD & SRL & VRD29d & LA & SDW & $\mathrm{R}: \mathrm{S}$ ratio \\
\hline \multirow[t]{2}{*}{ TRL } & LAl & 1 & & & & & & \\
\hline & HAl & 1 & & & & & & \\
\hline \multirow[t]{2}{*}{ MRD } & LAl & $0.53(\mathrm{~ns})$ & 1 & & & & & \\
\hline & HAl & $0.58(\mathrm{~ns})$ & 1 & & & & & \\
\hline \multirow[t]{2}{*}{ SRL } & LAl & $-0.39(\mathrm{~ns})$ & $-0.79 * *$ & 1 & & & & \\
\hline & HAl & $0.33(\mathrm{~ns})$ & $0.27(\mathrm{~ns})$ & 1 & & & & \\
\hline \multirow[t]{2}{*}{ VRD29d } & LAl & $0.65 *$ & $0.77 * *$ & $-0.33(\mathrm{~ns})$ & 1 & & & \\
\hline & HAl & $0.78 * *$ & $0.92 * * *$ & $0.34(\mathrm{~ns})$ & 1 & & & \\
\hline \multirow[t]{2}{*}{ LA } & LAl & $0.15(\mathrm{~ns})$ & $0.35(\mathrm{~ns})$ & $0.02(\mathrm{~ns})$ & $0.64 *$ & 1 & & \\
\hline & HAl & $0.52(\mathrm{~ns})$ & $0.14(\mathrm{~ns})$ & $0.22(\mathrm{~ns})$ & $0.31(\mathrm{~ns})$ & 1 & & \\
\hline \multirow[t]{2}{*}{ SDW } & LAl & $0.64 *$ & $0.57(\mathrm{~ns})$ & $-0.26(\mathrm{~ns})$ & $0.82 * *$ & $0.69 *$ & 1 & \\
\hline & HAl & $0.50(\mathrm{~ns})$ & $0.38(\mathrm{~ns})$ & $0.46(\mathrm{~ns})$ & $0.47(\mathrm{~ns})$ & $0.81 * *$ & 1 & \\
\hline \multirow[t]{2}{*}{$\mathrm{R}: \mathrm{S}$ ratio } & LAl & $0.47(\mathrm{~ns})$ & $0.68 *$ & $-0.79 * *$ & $0.24(\mathrm{~ns})$ & $-0.29(\mathrm{~ns})$ & $-0.02(\mathrm{~ns})$ & 1 \\
\hline & HAl & $0.81 * *$ & $0.70 *$ & $0.05(\mathrm{~ns})$ & $0.71 *$ & $0.15(\mathrm{~ns})$ & $0.11(\mathrm{~ns})$ & 1 \\
\hline Level of $\mathrm{Al}$ & 1 & $16524 * * *$ & 0.0007 (ns) & $12236 * * *$ & $1774 * * *$ & $811056 * * *$ & $19.58 * * *$ & $0.34 * * *$ \\
\hline Rep. (Al level) & 4 & $28.77(\mathrm{~ns})$ & 0.0009 (ns) & 299.3 (ns) & 420.9 (ns) & 2991 (ns) & $0.19(\mathrm{~ns})$ & $0.008(\mathrm{~ns})$ \\
\hline Genotype & 10 & $776.2 * * *$ & $0.009 * * *$ & $1342 * * *$ & $3747 * * *$ & 3235 (ns) & $0.28 *$ & $0.06 * * *$ \\
\hline Gen. $\times$ Al level & 10 & $100.3(\mathrm{~ns})$ & 0.0003 (ns) & $986.2^{* *}$ & $1815^{*}$ & $8193 *$ & $0.18(\mathrm{~ns})$ & $0.012 *$ \\
\hline Error & 40 & 138.9 & 0.0012 & 301.1 & 79.23 & 3773 & 0.119 & 0.004 \\
\hline
\end{tabular}

$n s$ Non significant

Statistical significance at the $* 0.5, * * 0.01$, and $* * * 0.001$ probability levels, respectively

HAl soil, TRL was correlated with only two root traits, VRD29d at 29 days $\left(r=0.78^{* *}\right)$ and root to shoot ratio (R:S) ratio $\left(r=0.81^{* *}\right)$; whereas MRD was highly correlated with VRD29d of 29 day-old plants $(r=0.92 * * *)$ (Table 5). This implies that thicker roots were penetrating deeper into soil, and reflects the fact that $P$. coccineus presented high values of both traits. However, thicker roots did not necessarily represent less efficient use of biomass, as indicated by values of SRL. Whereas HAl soil induced serious reductions in SRL in common bean in Trial 2, three of the runner bean accessions maintained their values of SRL. In Trial 3, G353462Q likewise showed a minimal reduction in SRL in acid soil. In both soil trials runner bean presented thicker roots than common bean under $\mathrm{Al}$ stress, and yet runner bean presented SRL that was greater than (in Trial 2) or comparable (in Trial 3) to common bean in $\mathrm{Al}$ stress, especially compared to the Mesoamerican genotypes SER 16, VAX 3 and VAX 6. This implies that the roots of runner bean are less dense than roots of common bean. This may be an expression of aerenchyma development in runner bean, which would be a very interesting trait to introgress to common bean. The tendency to thicker roots in $P$. coccineus was more evident in the soil experiments than in the hydroponic trials.

Tolerance to combined stress in soil

Aluminium levels $\times$ water regimes in Trial 3 effects were large for TRL and moderate for SRL. As expected, combined stress of Al-toxic soil and WS was the most inhibitory to TRL, followed by WS alone, and then by $\mathrm{Al}$ alone, based on the treatment averages (Table 6). However, as expected, Al-stress alone was more inhibitory than WS to SRL and VRD33d. Genotypes differed for all root traits considered (TRL, MRD, SRL, and VRD33d) (Table 7). Two sister lines of $P$. coccineus, G35346-3Q and G35346-2Q, were the most tolerant to combined stress, presenting the highest values of 


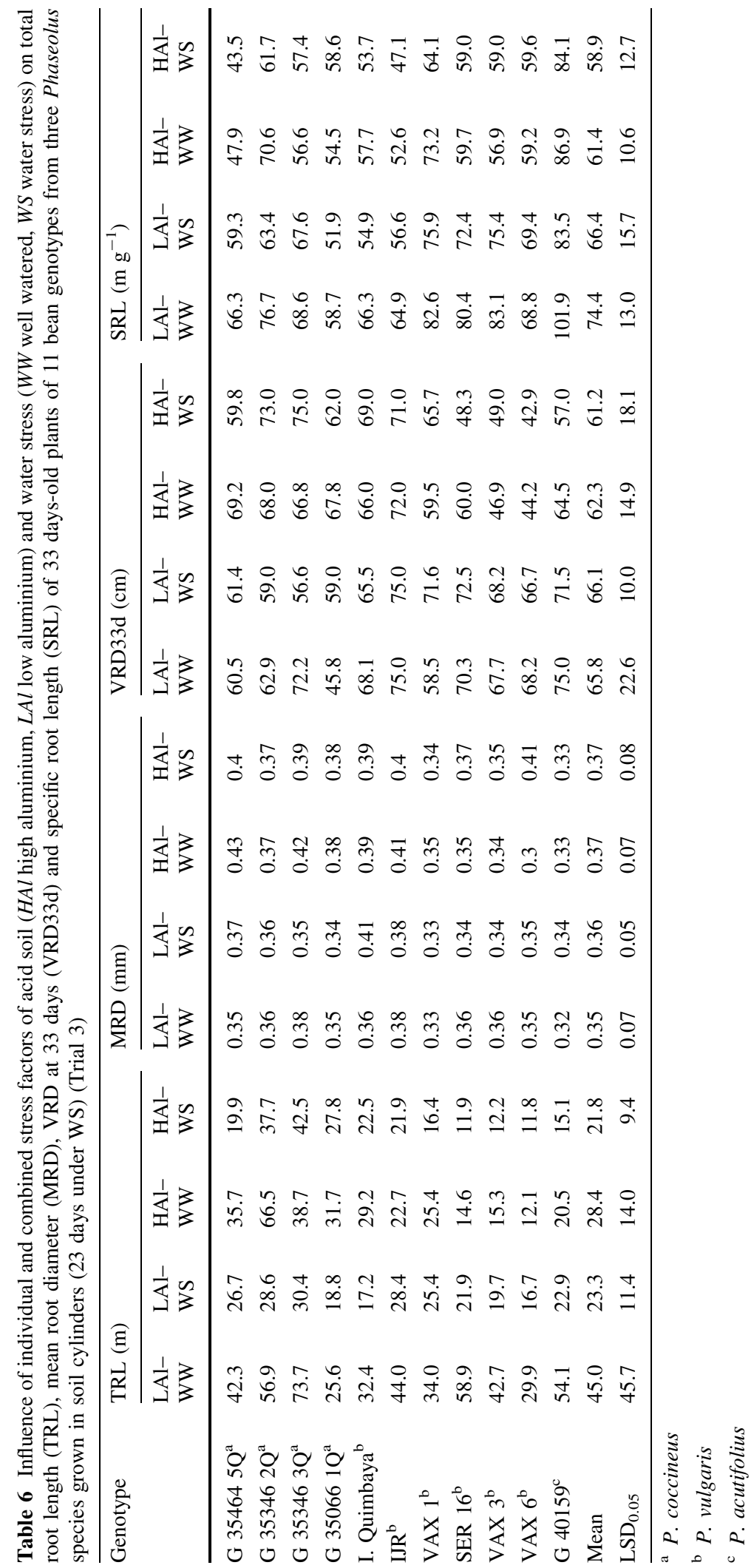


Table 7 Correlation coefficients and mean squares for total root length (TRL), mean root diameter (MRD), specific root length (SRL), VRD at 33 days (VRD33d), leaf area (LA), shoot dry weight (SDW), root:shoot ratio (R:S ratio) of 11 bean genotypes grown under combined stress of $\mathrm{Al}$ and water stress (23 days under WS) (Trial 3)

\begin{tabular}{|c|c|c|c|c|c|c|c|c|}
\hline Traits/source & $\mathrm{DF}$ & TRL & MRD & VRD33d & SRL & LA & SDW & $\mathrm{R}: \mathrm{S}$ ratio \\
\hline TRL & - & 1 & & & & & & \\
\hline MRD & - & $0.43 *$ & 1 & & & & & \\
\hline VRD33d & - & $0.79 * * *$ & 0.27 (ns) & 1 & & & & \\
\hline SRL & - & $-0.2(\mathrm{~ns})$ & $-0.62 * * *$ & $-0.11(\mathrm{~ns})$ & 1 & & & \\
\hline LA & - & $0.62 * * *$ & $0.56 * * *$ & $0.58 * * *$ & $-0.39 *$ & 1 & & \\
\hline SDW & - & $0.82 * * *$ & $0.55 * * *$ & $0.59 * * *$ & $-0.42 *$ & $0.62 * * *$ & 1 & \\
\hline $\mathrm{R}: \mathrm{S}$ ratio & - & $0.57 * * *$ & 0.19 (ns) & $0.59 * * *$ & $-0.06(\mathrm{~ns})$ & $0.32(\mathrm{~ns})$ & $0.10(\mathrm{~ns})$ & 1 \\
\hline Rep & 2 & $347.1 *$ & $0.004 * *$ & 12.7 & $344.6 * * *$ & 1.45 & 0.013 & 0.040 \\
\hline Water & 1 & $6582.4^{*}$ & 0.000 & 6.0 & 909.5 & $405.55^{* *}$ & $12.597 * *$ & 0.749 \\
\hline Rep $\times$ water & 2 & $390.2 *$ & 0.001 & $212.0 *$ & 67.1 & 4.53 & 0.061 & $0.101 *$ \\
\hline $\mathrm{Al}$ & 1 & $2700.9 * * *$ & $0.009 * *$ & $598.0 * *$ & $3444.6 * * *$ & $417.00 * * *$ & $9.855 * *$ & $0.804 * *$ \\
\hline Water $\times \mathrm{Al}$ & 1 & $1867.5^{* * *}$ & 0.000 & 15.4 & $246.0 *$ & $170.83 * * *$ & $3.437 *$ & 0.016 \\
\hline Rep $\times$ water $\times \mathrm{Al}$ & 4 & 5.8 & 0.000 & 10.8 & 24.9 & 1.63 & 0.211 & 0.030 \\
\hline Genotype & 10 & $1023.5^{* * *}$ & $0.005 * * *$ & $313.9 * * *$ & $1244.2 * * *$ & $13.55^{* *}$ & $0.435^{*}$ & $0.355^{* * *}$ \\
\hline $\mathrm{Al} \times$ genotype & 10 & $386.7 * * *$ & 0.001 & $463.6 * * *$ & $128.4 * * *$ & $24.11 * * *$ & $0.819 * * *$ & $0.088 * *$ \\
\hline Water $\times$ genotype & 10 & 150.2 & 0.001 & 57.9 & 48.2 & 9.78 & 0.238 & 0.026 \\
\hline Water $\times \mathrm{Al} \times$ genotype & 10 & 184.1 & 0.002 & $104.1 *$ & 21.2 & $17.74 * * *$ & 0.241 & 0.060 \\
\hline Error & 80 & 113.5 & 0.001 & 52.6 & 31.4 & 5.23 & 0.219 & 0.032 \\
\hline
\end{tabular}

$n s$ Non significant, $W r$ water regime

Statistical significance at the * $0.5, * * 0.01$, and $* * * 0.001$ probability levels, respectively

TRL and maintaining a deeper root system (Tables 6, 8). They were also the two best under Al-stress alone but showed difficulties to develop a deep rooting system under WS alone. Other relatively tolerant genotypes in combined stress were G35066-1Q and ICA Quimbaya. Interactions of genotype $\times$ Al treatment were highly significant for TRL, SRL, and VRD (Table 7). Although combined stress of $\mathrm{Al}$ and WS is generally more damaging than each stress considered separately, in this study an unexpected interaction between these two stress factors was observed. $P$. coccineus accessions (G35346-3Q, G35346-2Q, and G35066-1Q) and to lesser extent ICA Quimbaya developed more roots, and showed deeper rooting based on VRD33d with the combined $\mathrm{Al}$ and WS than with WS alone (Table 6). TRL was correlated with MRD $\left(r=0.43^{*}\right)$, and with root depth $(r=0.79 * * *)$ in the combined stress treatment, whereas MRD was negatively correlated with SRL $(r=-0.62 * * *)$ as expected (Table 7).
Root length and dry weight distribution

Results on genotypic differences in rooting strategies estimated by the values of the extinction coefficient $\beta$ for root length distribution in Trials 2 and 3 showed that the accessions of $P$. coccineus had greater proportion of root length at depth than the other genotypes except for the Andean genotype IJR under HAl treatment in both WW as well as WS conditions (Table 8). Similar effects were observed on $\beta$ values for root biomass distribution (Table 9).

\section{Root and shoot attributes}

Shoot traits were measured only in the soil cylinder trials. If an improved root system with $\mathrm{Al}$ resistance is to result in yield improvement, it is important that it contribute to enhanced shoot development. Estimation of shoot vigor of plants grown in acid soil was made based on LA development and SDW under individual (Trial 2) and combined stress of Al and WS (Trial 3). 

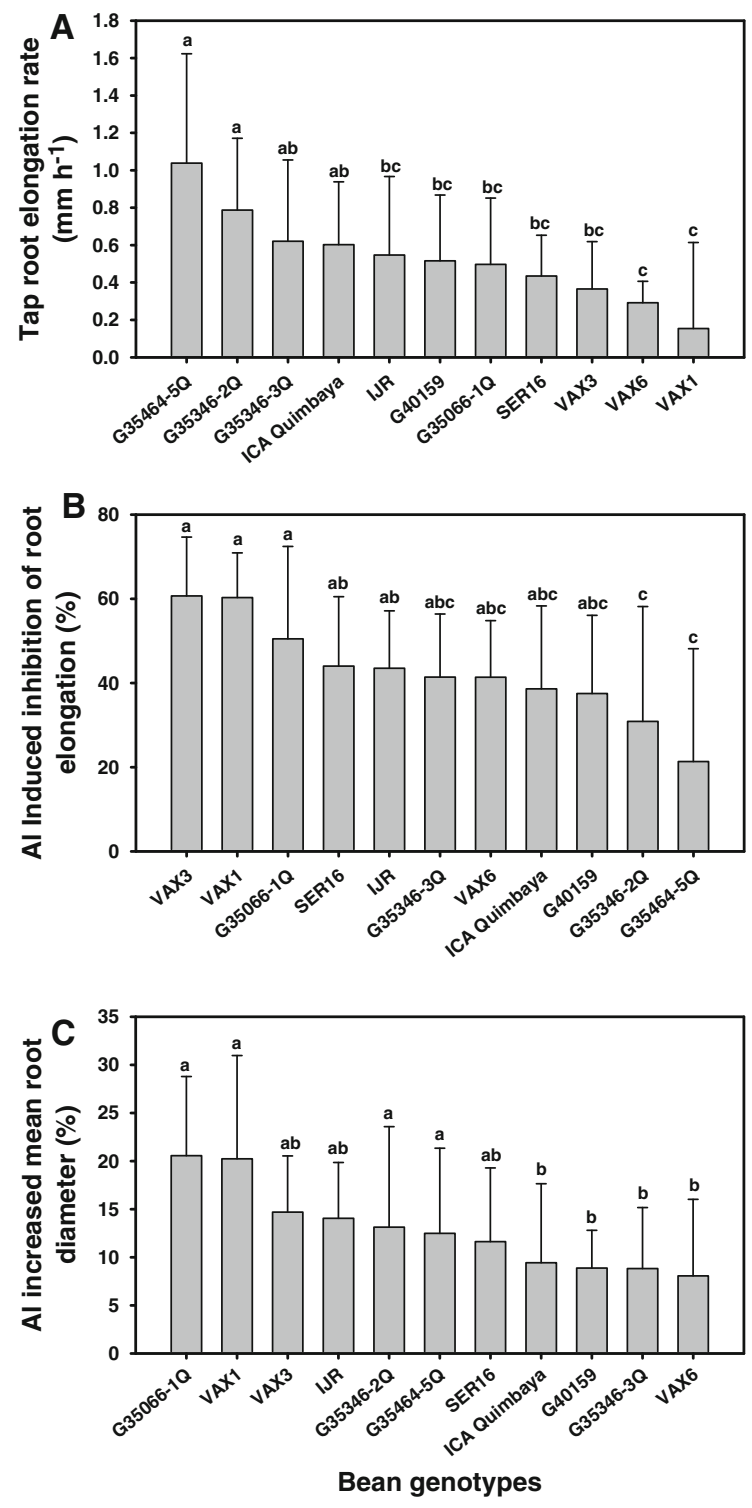

Fig. 1 Root parameters of 11 bean genotypes grown under hydroponic system under two levels of $\mathrm{Al}(20 \mu \mathrm{M} \mathrm{Al}$ and $0 \mu \mathrm{M} \mathrm{Al}$ ) at $\mathrm{pH} 4.5$ (Trial 1). A TRER in mm per hour under $\mathrm{HAl}(20 \mu \mathrm{M} \mathrm{Al})$; B Al-induced inhibition of TRER in per cent; C Al-induced increase of MRD in per cent. Bars represent means $\pm \mathrm{SD}$, with 4 replicates. Different letters indicate differences between at $P<0.05$ (REGWQ test)

G35346-2Q was the best genotype under Al-stress alone for combining an extensive root system, large leaves and vigorous seedlings. G35346-3Q was found to be the best with similar potential under combined stress of $\mathrm{Al}$ and $\mathrm{WS}$, but was intermediate for $\mathrm{Al}$ alone for both traits, and was very poor for WS alone
(Table 10). Genotype $\times \mathrm{Al}$ level interaction was significant for LA and R:S ratio and a highly significant interaction was observed for genotype $\times(\mathrm{Al}$ and water regime) for LA and R:S ratio and SDW (Table 7). Larger LA development was accompanied by strong shoot biomass investment in stems, branches and petioles. $P$. vulgaris genotypes SER16 and VAX1, and $P$. acutifolius G40159 expressed relatively higher values of LA and shoot biomass under drought stress, but were strongly affected by Al-toxic acid soil, and were more sensitive in shoot parameters under combined stress factors of $\mathrm{Al}$ and WS (Table 10), indicating that their capacity to acquire nutrients and water for shoot growth was reduced.

The relationships between shoot traits (LA and SDW) and TRL in Al stress alone (Trial 2) and in combined stress of $\mathrm{Al}$ and WS (Trial 3) in soil cylinder system were analysed. Linear regression of LA on TRL in Al stress for the 11 genotypes showed positive relationship $(r=0.81 *)$ (Fig. 2A), and a similar relationship was observed between SDW and TRL $\left(r=0.83^{*}\right)$ (Fig. 2B) in Al stress. Relationship between SDW and TRL in combined stress of Al and WS also showed a strong positive relationship ( $r=0.81^{*}$ ) (Fig. 2C). The accessions of P. coccineus in most cases presented the highest values and influenced the regression values heavily. The genotypes G35346-2Q, G35346-3Q and G35464-5Q were outstanding under $\mathrm{Al}$ stress expressing a deeper root system (Table 4) and maintaining above average shoot development. All P. vulgaris cultivars and the $P$. acutifolius accession performed poorly in root development and LA production with the exception of an Andean bean type IJR that was intermediate (Fig. 3A). Roots can exert indirect control on leaf growth which depends on the supply of cytokinins and water from roots (Lambers et al. 1995). Results from short-term experiments indicated that at low nutrient availability some species with a high potential root growth rate still grow faster than those with low potential root growth rate and have greater capacity to acquire nutrients (Chapin 1980; Lambers and Poorter 1992; Ryser and Lambers 1995).

\section{Root traits across experiments}

TRL was analysed at two levels of Al treatment both in hydroponic and soil cylinder experiments. There was a strong linear relationship between TRL per 
Table 8 Influence of individual and combined stress factors of acid soil (HAl high aluminium, $L A l$ low aluminium) and water stress ( $W W$ well watered, WS water stress) on root length distribution estimated by root length extinction coefficient $\beta$,

\begin{tabular}{|c|c|c|c|c|c|c|}
\hline \multirow[t]{3}{*}{ Genotype } & \multicolumn{2}{|c|}{ Individual Al stress } & \multicolumn{4}{|c|}{ Combined $\mathrm{Al}$ and water stress } \\
\hline & \multirow[t]{2}{*}{ HAl } & \multirow[t]{2}{*}{ LAl } & \multicolumn{2}{|l|}{ WW } & \multicolumn{2}{|l|}{ WS } \\
\hline & & & HAl & LAl & $\mathrm{HAl}$ & LAl \\
\hline G $354645 Q^{a}$ & 0.9609 & 0.9607 & 0.9664 & 0.9599 & 0.9640 & 0.9555 \\
\hline G $353462 Q^{a}$ & 0.9628 & 0.9611 & 0.9666 & 0.9615 & 0.9642 & - \\
\hline G $353463 Q^{a}$ & 0.9507 & 0.9642 & 0.9685 & 0.9691 & 0.9672 & 0.9616 \\
\hline G $350661 Q^{a}$ & 0.9411 & 0.9569 & 0.9578 & 0.9452 & 0.9584 & 0.9206 \\
\hline ICA Quimbaya $^{\mathrm{b}}$ & 0.9562 & 0.9623 & 0.9599 & 0.9520 & 0.9529 & 0.9550 \\
\hline $\mathrm{IJR}^{\mathrm{b}}$ & 0.9516 & 0.9684 & 0.9660 & 0.9690 & 0.9663 & 0.9759 \\
\hline VAX $1^{b}$ & 0.9397 & 0.9514 & 0.9486 & 0.9486 & 0.9479 & 0.9589 \\
\hline SER $16^{\mathrm{b}}$ & 0.9372 & 0.9563 & 0.9480 & 0.9680 & 0.9479 & 0.9644 \\
\hline $\operatorname{VAX} 3^{\mathrm{b}}$ & 0.9369 & 0.9574 & 0.9442 & 0.9610 & 0.9386 & 0.9617 \\
\hline $\operatorname{VAX} 6^{\mathrm{b}}$ & 0.9492 & 0.9495 & 0.9230 & 0.9466 & 0.9381 & 0.9596 \\
\hline $\mathrm{G} 40159^{\mathrm{c}}$ & 0.9504 & 0.9672 & 0.9498 & 0.9603 & 0.9512 & 0.9714 \\
\hline Mean & 0.9488 & 0.9596 & 0.9544 & 0.9583 & 0.9542 & 0.9585 \\
\hline $\mathrm{LSD}_{0.05}$ & NS & $0.101 *$ & $0.0168 * * *$ & NS & $0.0167 *$ & $0.0179 *$ \\
\hline
\end{tabular}

${ }^{a}$ P. coccineus

b $P$. vulgaris

c P. acutifolius

plant under $20 \mu \mathrm{M} \mathrm{Al}$ and the control with $0 \mu \mathrm{M} \mathrm{Al}$ in hydroponic system $(r=0.94)$ (Fig. 3A). For soil cylinder system, the linear relationship between TRL under $\mathrm{LAl}$ and $\mathrm{HAl}$ saturation was also strong ( $r=0.84)$ (Fig. 3B). Four $P$. coccineus accessions (G35464-5Q, G35346-2Q, G35346-3Q, and G350661Q) showed greater values of TRL both with and without $\mathrm{Al}$ in hydroponic system, and in soil cylinder studies, three of these (G35346-2Q, G35346-3Q, and G35464-5Q) maintained good root development with either LAl or HAl saturation. The two screening methods were highly correlated $\left(r=0.85^{* * *}\right)$ for TRL in HAl soil and in nutrient solution with $20 \mu \mathrm{M}$ $\mathrm{Al}$ (Fig. 3C), although correlation was driven in large part by the values of the $P$. coccineus accessions. A significant but lower correlation $\left(r=0.69^{*}\right)$ was found between TRL in LAl soil and nutrient solution without Al in hydroponic system (Fig. 3D). Several authors have examined the relationship of response with different screening methods with varying results. Narasimhamoorthy et al. (2007) compared three methods including hydroponics, soil, and root staining for evaluation of $\mathrm{Al}$ tolerance in Medicago that describes the shape of the cumulative root length distribution with depth, of 11 bean genotypes from three Phaseolus species grown in soil cylinders (Trial 3) 
Table 9 Influence of individual and combined stress factors of acid soil (HAl high aluminium, $L A l$ low aluminium) and water stress ( $W W$ well watered, $W S$ water stress) on root biomass distribution estimated by root biomass extinction coefficient $\beta$, that describes the shape of the cumulative root biomass distribution with depth, of 11 bean genotypes from three Phaseolus species grown in soil cylinders (Trial 3)

\begin{tabular}{|c|c|c|c|c|c|c|}
\hline \multirow[t]{3}{*}{ Genotype } & \multicolumn{2}{|c|}{ Individual Al stress } & \multicolumn{4}{|c|}{ Combined $\mathrm{Al}$ and water stress } \\
\hline & \multirow[t]{2}{*}{ HAl } & \multirow[t]{2}{*}{ LAl } & \multicolumn{2}{|l|}{ WW } & \multicolumn{2}{|l|}{ WS } \\
\hline & & & HAl & LAl & HAl & LAl \\
\hline G $354645 Q^{a}$ & 0.9560 & 0.9574 & 0.9635 & 0.9535 & 0.9591 & 0.9513 \\
\hline G $353462 Q^{a}$ & 0.9603 & 0.9583 & 0.9639 & 0.9593 & 0.9628 & - \\
\hline G $353463 Q^{a}$ & 0.9467 & 0.9594 & 0.9649 & 0.9663 & 0.9637 & 0.9578 \\
\hline $\mathrm{G} 350661 \mathrm{Q}^{\mathrm{a}}$ & 0.9401 & 0.9545 & 0.9537 & 0.9397 & 0.9528 & 0.9001 \\
\hline ICA Quimbaya ${ }^{\mathrm{b}}$ & 0.9495 & 0.9572 & 0.9575 & 0.9470 & 0.9495 & 0.9431 \\
\hline $\mathrm{IJR}^{\mathrm{b}}$ & 0.9474 & 0.9606 & 0.9642 & 0.9675 & 0.9616 & 0.9720 \\
\hline $\operatorname{VAX} 1^{\mathrm{b}}$ & 0.9416 & 0.9516 & 0.9505 & 0.9406 & 0.9465 & 0.9546 \\
\hline SER $16^{\mathrm{b}}$ & 0.9544 & 0.9544 & 0.9485 & 0.9637 & 0.9400 & 0.9581 \\
\hline $\operatorname{VAX} 3^{\mathrm{b}}$ & 0.9321 & 0.9540 & 0.9516 & 0.9572 & 0.9356 & 0.9573 \\
\hline VAX $6^{\mathrm{b}}$ & 0.9467 & 0.9451 & 0.9249 & 0.9417 & 0.9327 & 0.9526 \\
\hline $\mathrm{G} 40159^{\mathrm{c}}$ & 0.9448 & 0.9647 & 0.9468 & 0.9559 & 0.9497 & 0.9673 \\
\hline Mean & 0.9472 & 0.9561 & 0.9536 & 0.9538 & 0.9504 & 0.9514 \\
\hline $\mathrm{LSD}_{0.05}$ & NS & NS & $0.0131 * * *$ & NS & $0.0168 * *$ & $0.0163^{*}$ \\
\hline
\end{tabular}

${ }^{\mathrm{a}}$ P. coccineus

b $P$. vulgaris

c P. acutifolius

be tolerant in soil-based assays with older plants (Armiger et al. 1968; Foy et al. 1969, 1992; Devine et al. 1979; Sapra et al. 1982; Horst and Klotz 1990). VAX1 which was found to be Al sensitive in hydroponic system was found to be acid soil tolerant under field conditions because of its abundant adventitious root system that helped avoid $\mathrm{Al}$ toxicity.

In our experience with the hydroponic system and in Al-toxic acid soil, each screening method permitted evaluation of different aspects of root behaviour. For example, the hydroponic system enabled quantification of NRT (the most Al-sensitive part of the root) which was not possible with soil cylinders after cutting the cylinders at different soil depths, whereas soil based screening revealed rooting ability to penetrate Al-toxic soil. In this sense the two methods were complementary. A strong relationship was observed between $\mathrm{Al}$ resistance in hydroponics and acid soil tolerance for some specific root traits. Significant correlations were found between three root traits from hydroponic evaluation (TRL, TPRL120h and SRL) and three other root traits from soil cylinder evaluation (TRL, VRD and MRD).
Villagarcia et al. (2001) concluded that some genetic sources will lend themselves well to hydroponicsbased screening while others may not. Of these traits, TRL and VRD in soil are those that we interpret as being the most relevant measures of root health in an Al toxic environment.

On the other hand, no significant correlation was found between SRL in hydroponic and soil cylinder experiments, and genotypic ranking based on SRL in nutrient solution with $20 \mu \mathrm{M} \mathrm{Al}$ did not agree with the ranking in Al-toxic acid soil. While some traits express similarly in the two systems, others apparently do not. An unusual relationship was observed between SRL and MRD. In the hydroponic system the correlation of SRL and MRD was highly negative as expected: $-0.84 * * *$ at $0 \mu \mathrm{M} \mathrm{Al}$ and $-0.87 * * *$ with $20 \mu \mathrm{M} \mathrm{Al}$. With LAl stress in soil, the correlation of SRL and MRD presented a similar value: $-0.79^{* * *}$. But in Al-toxic acid soil, the correlation was slightly positive $(0.27$; NS). This difference reflects a contrasting response of roots in soil as compared to the hydroponic system that seems to be due to $P$. coccineus. 


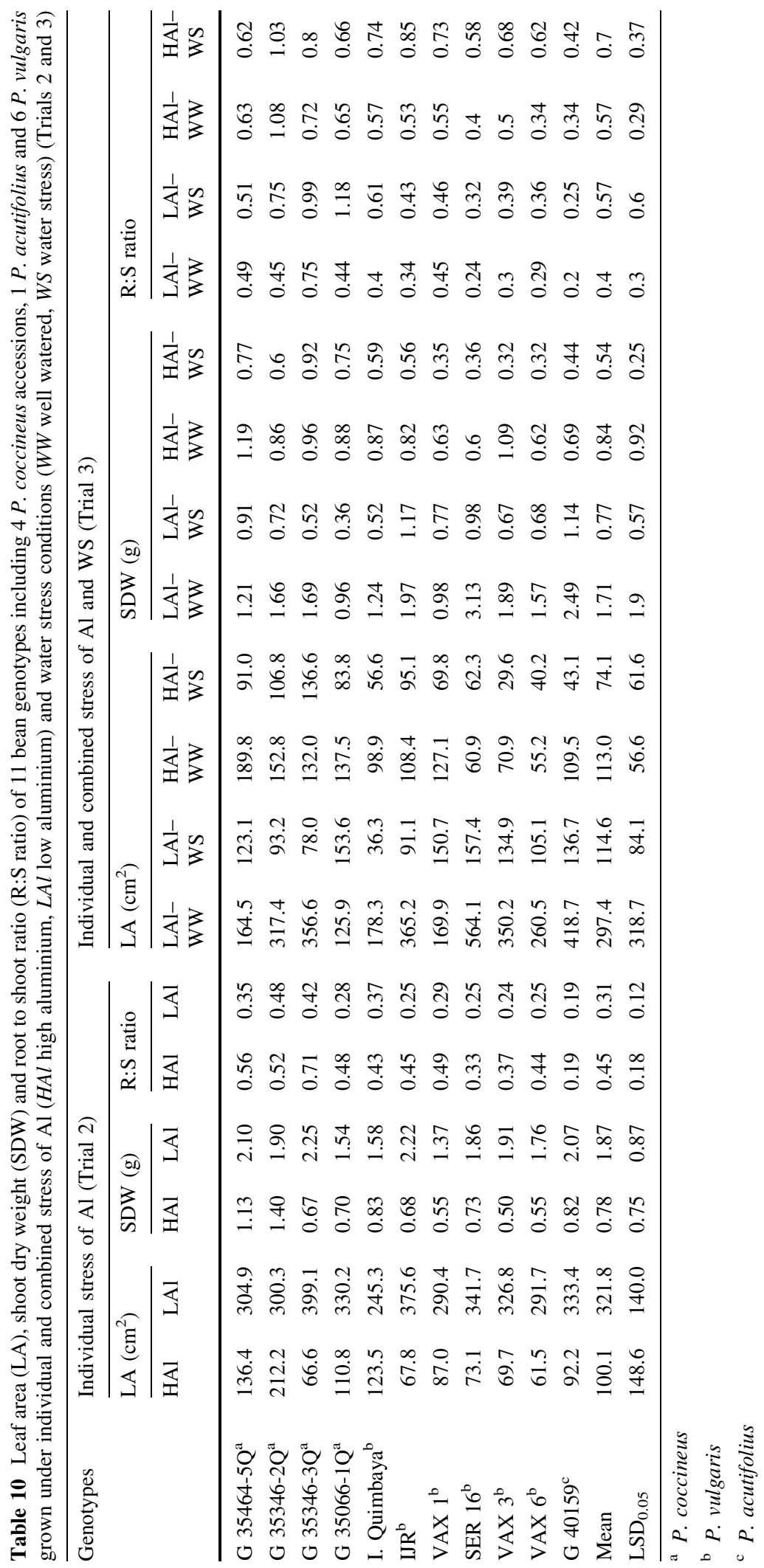



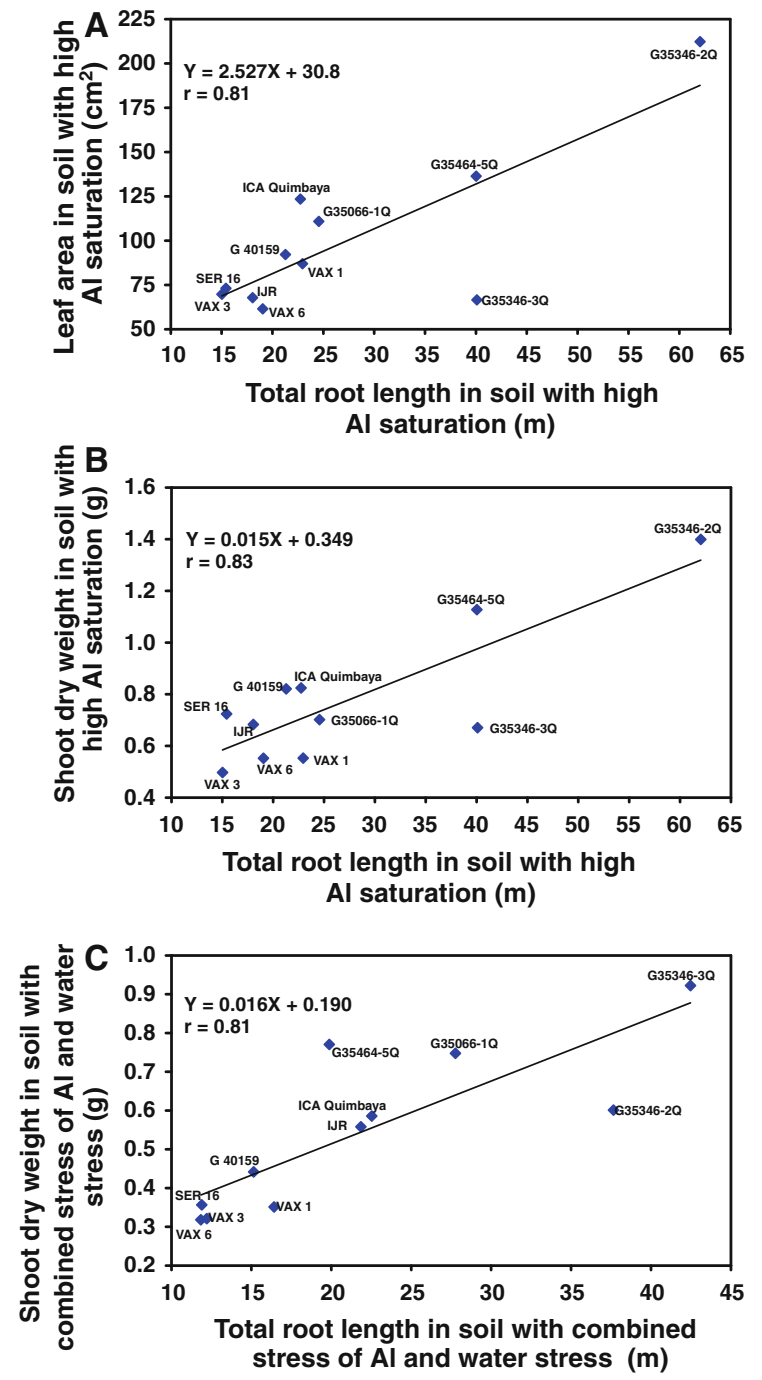

Fig. 2 Relationship between TRL and shoot attributes of 11 bean genotypes under individual and combined stress of $\mathrm{Al}$ and WS (Trial 3). A LA as influenced by TRL under Al toxic acid soil stress; B SDW as influenced by TRL under Al toxic acid soil stress; C SDW as influenced by TRL under combined stress of Al toxic acid soil and WS

\section{General discussion}

The nature of response to Al toxicity may be either non-specific and constitutive or specific. A reaction that is specific to $\mathrm{Al}$ ought to be associated with an interaction term of Genotype $\times \mathrm{Al}$ level in the analysis of variance. Comparing TRL with and without $\mathrm{Al}$ in hydroponic evaluation (Fig. 3A) we found that the correlation between them was high

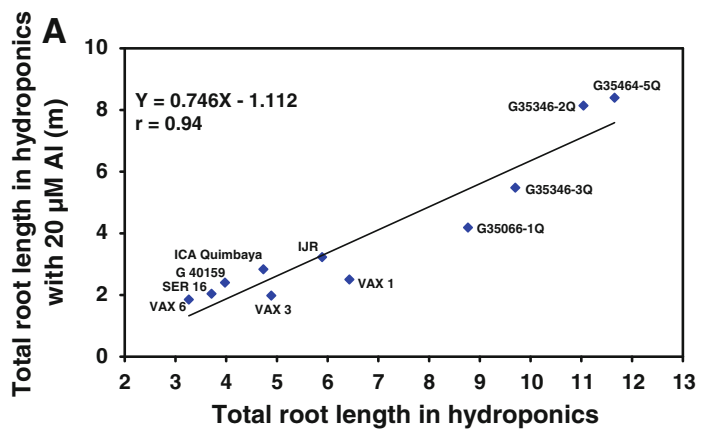
with $0 \mu \mathrm{M} \mathrm{Al}(\mathrm{m})$
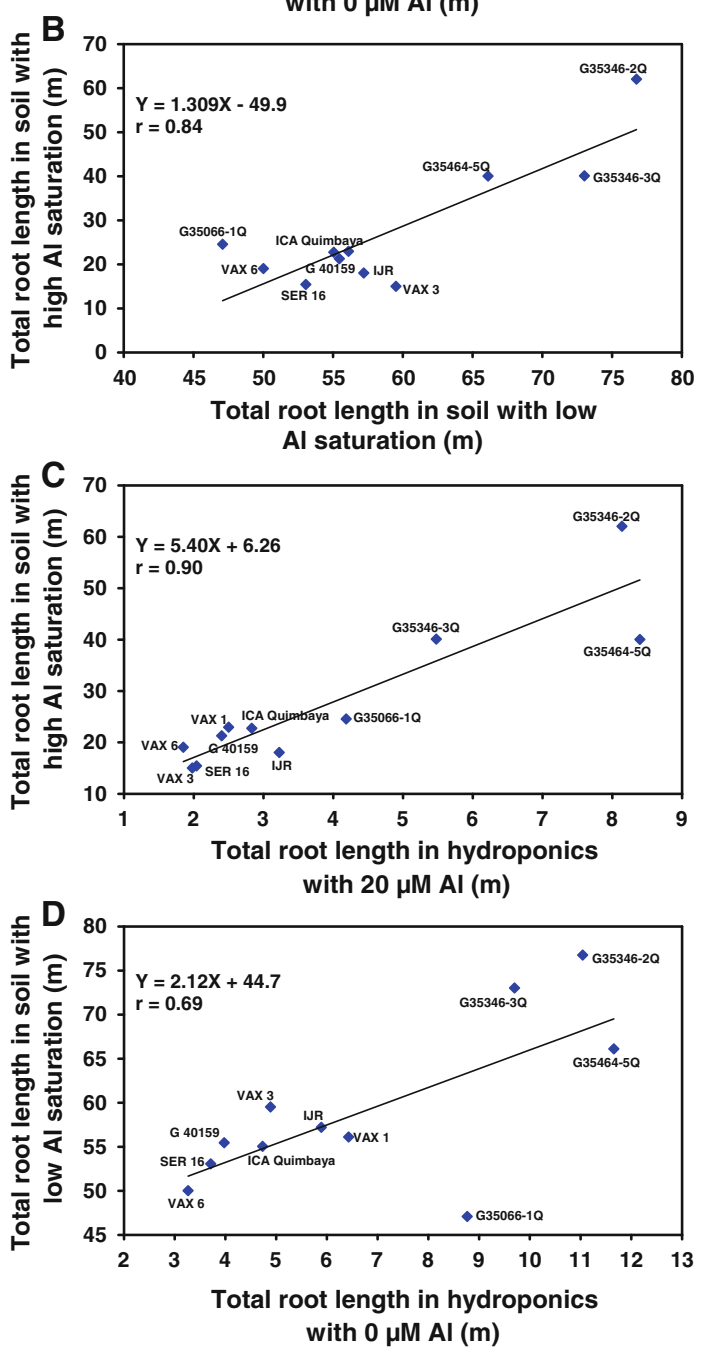

Fig. 3 Relationship between TRL of 11 bean genotypes in Al treatment in hydroponics with 0 and $20 \mu \mathrm{M} \mathrm{Al}$ (Trial 1), and soil cylinders with LAl and HAl saturation soil (Trial 2): A TRL in hydroponics with 0 and $20 \mu \mathrm{M} \mathrm{Al}$; B TRL in soil with LAl and HAl saturation soil; C TRL in hydroponics with $20 \mu \mathrm{M}$ Al versus $\mathrm{HAl}$ saturation in soil; D TRL in hydroponics with $0 \mu \mathrm{M} \mathrm{Al}$ versus LAl saturation in soil 
$(r=0.94 * * *)$. Genotype $\times$ Al level interaction was also significant but at $P<0.05$. Effects of both $\mathrm{Al}$ and genotype were highly significant. In contrast genotype $\times$ Al treatment was not significant in soil cylinder system suggesting that whatever effect of $\mathrm{Al}$ that resulted in much less TRL was not an effect for which lines express differential resistance for Al. The relationship of TRL with and without $\mathrm{Al}$ stress for soilbased screening (Fig. 3B) was also strong $(r=0.84)$, and three $\mathrm{Al}$ resistant $P$. coccineus accessions form a separate group from all the other genotypes. The high relationship of stressed and unstressed treatments implies that differences among genotypes were largely constitutive. Urrea-Gómez et al. (1996) suggested that constitutive morphological characteristics such as vigorous rooting could be advantageous in the breeding of Al-resistant cultivars.

One underlying issue that may influence plant response is the initial vigour of the seedlings, reflecting differences in seed size. Accessions of $P$. coccineus have larger seed size than $P$. vulgaris, and Andean beans are larger than Mesoamerican types. While this effect can not be discounted, $P$. coccineus displays traits that are independent of vigour per se and that set it off from $P$. vulgaris, such as: higher R:S ratio; increase of TRER at the $120 \mathrm{~h}$ measurement compared to the $48 \mathrm{~h}$ measurement; the maintenance of SRL in spite of Al toxicity; a positive response to combined stress of Al toxicity and WS in soil compared to WS alone. These observations argue in favour of unique mechanisms in $P$. coccineus that could make a valuable contribution to the improvement of common bean.

Although closely related to common bean, $P$. coccineus appears to have evolved for adaptation in different environments, and with different strategies. Many accessions originate in high rainfall areas on volcanic soils, possibly with low $\mathrm{pH}$ and some degree of $\mathrm{Al}$ stress, leading to adaptation to $\mathrm{Al}$ toxic soil. On the other hand, its root system is especially poor under WS in the soil cylinders, with less penetration than any of the common bean lines. In the moist environment in which it evolved a deep rooting trait was not an advantage. The resistance to $\mathrm{Al}$ toxicity in $P$. coccineus illustrates the value of the broad genetic variability of the Phaseolus genus, and especially the secondary gene pool of $P$. vulgaris that can be crossed readily with common bean. $P$. coccineus, and $P$. dumosus have been employed in interspecific crosses for the improvement of common bean before, but in most cases for disease resistance, given their adaptation to humid environments where disease pressure is intense. Their importance could increase under the threat of climate change and increased rainfall in some tropical regions. However, this is the first report that we are aware of, identifying sources for abiotic stress resistance in these species. While readily crossable to common bean, progenies of interspecific hybridizations are often of poor agronomic value. We are investigating ways to take better advantage of these species through interspecific crosses. Given the superior reaction of G35346-3Q in the treatment of combined $\mathrm{Al}$ and WS treatment, it was chosen for crossing with common bean.

These studies also confirmed the superiority in $\mathrm{Al}$ response of Andean common beans compared to Mesoamerican types for several important traits under Al toxicity in the hydroponic system (e.g., TPRL120h, or TRL) or acid soil stress (e.g., TRL or VRD). This confirms previous reports on Andean and Mesoamerican genotypes (Rangel et al. 2005, 2007; Blair et al. 2009; López-Marín et al. 2009). Only one accession of $P$. acutifolius was included in this study, but it was distinguished by its consistently greater values of SRL and correspondingly thinner roots, in both the hydroponic system and in soil cylinders, and under either stress. This species evolved in a semiarid to arid environment in northwest Mexico and southwest United States in which Al toxicity would not be a problem. It also presented good VRD in several treatments in the soil cylinder experiments.

\section{Conclusions}

The greater level of Al-resistance found in $P$. coccineus accessions (G35346-2Q and G35464-5Q) offers the opportunity to obtain much better $\mathrm{Al}$ resistance in common bean through interspecific crosses. Another P. coccineus accession G35346-3Q identified in this study showed the ability to tolerate combined stress factors of $\mathrm{Al}$ and WS. Given that abiotic stresses often co-occur in farmers fields, the use of this genotype in common bean improvement for resistance to these two stress factors is likely to be more productive than considering resistance to stresses in isolation. Populations created from multiple stress resistance donors could be more stable and 
capable to produce grain under stress in the face of climate change.

Acknowledgments This research was supported by Bundesministerium für Wirtschaftliche Zusammenarbeit und Entwicklung (BMZ) project (No. 05.7860.9-001.00) entitled "Fighting drought and aluminum toxicity: Integrating functional genomics, phenotypic screening and participatory evaluation with women and small-scale farmers to develop stress-resistant common bean and Brachiaria for the tropics". We are very grateful to research support staff of CIAT bean program for their assistance in data collection and processing.

\section{References}

Armiger WH, Foy CD, Fleming AL, Caldwell BE (1968) Differential tolerance of soybean varieties to an acid soil high in exchangeable aluminum. Agron J 60:67-70

Bianchi-Hall CM, Carter TE Jr, Rufty TW, Arellano C, Boerma HR, Ahley DA, Burton JW (1998) Heritability and resource allocation of aluminum tolerance derived from soybean PI 416937. Crop Sci 38:513-522

Bianchi-Hall CM, Carter TE Jr, Bailey MA, Mian MAR, Rufty TW, Ashley DA, Boerma HR, Arellano C, Hussey RS, Parrott WA (2000) Aluminum tolerance associated with quantitative trait loci derived from soybean PI416937 in hydroponics. Crop Sci 40:538-545

Blair MW, López-Marín HD, Rao IM (2009) Identification of aluminum resistant Andean genotypes of common bean (Phaseolus vulgaris L.). Braz J Plant Physiol 21(4): 291-300

Campbell KAG, Carter TE Jr (1990) Aluminum tolerance in soybean. I. Genotypic correlation and repeatability of solution culture and greenhouse screening methods. Crop Sci 30:1049-1054

Carter TE Jr, Rufty TW (1993) Soybean plant introductions exhibiting drought and aluminum tolerance. In: Kuo CG (ed) Adaptation of food crops to temperature and water stress: proceedings of an international symposium, Taiwan, 13-18 Aug 1992. Publi. no. 93-410. Asian Vegetable Research and Development Center, Shanhua, pp 335-346

Chapin FS (1980) The mineral nutrition of wild plants. Annu Rev Ecol Syst 11:233-260

Choi HK, Mun JH, Jin Kim DJ, Zhu H, Baek JM, Mudge J, Roe B, Ellis N, Doyle J, Kiss GB et al (2004) Estimating genome conservation between crop and model legume species. Proc Natl Acad Sci USA 101:15289-15294

CIAT (2005) Bean improvement for the tropics. Project IP-1, annual report 2005. Cali

CIAT (2008) Improved beans for the developing world. Outcome line SBA-1. Annual report 2008. Cali

Delhaize E, Ryan PR (1995) Aluminum toxicity and tolerance in plants. Plant Physiol 107:315-321

Devine TE, Foy CD, Mason DL, Fleming AL (1979) Aluminum tolerance in soybean germplasm. Soybean Genet Newsl (Ames) 6:763-782

Eisenstat DM (1992) Costs and benefits of constructing roots of small diameter. J Plant Nutr 15:763-782
Eticha D, Zahn M, Bremer M, Yang Z, Rangel AF, Rao IM, Horst WJ (2010) Transcriptomic analysis reveals differential gene expression in response to aluminium in common bean (Phaseolus vulgaris) genotypes. Ann Bot 105: 1119-1128

Foy CD (1988) Plant adaptation to acid, aluminum-toxic soils. Commun Soil Sci Plant Anal 19:959-987

Foy CD, Fleming AL, Armiger WJ (1969) Aluminum tolerance of soybean varieties in relation to calcium nutrition. Agron J 61:505-511

Foy CD, Duke JA, Devine TE (1992) Tolerance of soybean germplasm to an acid tatum subsoil. J Plant Nutr 15: 527-547

Gale MR, Grigal DF (1987) Vertical root distribution of northern tree species in relation to successional status. Can J For Res 17:829-834

Girdthai T, Joglory S, Kesmala T, Vorasoot N, Akkasaeng C, Wongkaew S, Holbrook CC, Patanothai A (2010) Relationship between root characteristics of peanut in hydroponics and pot studies. Crop Sci 50:159-167

Horst WJ, Klotz F (1990) Screening soybean for aluminum tolerance and adaptation to acid soils. In: El Bassam $\mathrm{N}$ et al (eds) Genetic aspects of plant mineral nutrition. Kluwer Academic Publishers, Dordrecht, pp 355-360

Horst WJ, Wang Y, Eticha D (2010) The role of the root apoplast in aluminium-induced inhibition of root elongation and in aluminium resistance of plants: a review. Ann Bot 106:185-197

Johansen C, Baldev B, Brouwer JB, Erskine W, Jermyn WA, Lang LJ, Malik BA, Miah AA, Silim SN (1994) Biotic and abiotic stresses constraining productivity of cool season food legumes in Asia, Africa and Oceania. In: Muehlbauer FJ, Kaiser WJ (eds) Expanding the production and use of cool season food legumes. Kluwer Academic Publishers, Dordrecht, pp 175-194

Kerven GL, Edwards DG, Asher CJ, Hallman PS, Kobot S (1989) Aluminium determination in soil solution. II. Short-term colorimetric procedure for the measurement of inorganic monomeric aluminium in the presence of organic acid ligands. Aust J Soil Res 27:91-102

Lambers H, Poorter H (1992) Inherent variation in growth rate between higher plants: a search for physiological causes and ecological causes and ecological consequences. Adv Ecol Res 23:87-261

Lambers H, Nagel OW, van Arendonk JJCM (1995) The control of biomass partitioning in plants from "favourable" and "stressful" environments: a role for gibberellins and cytokinins. Bulg J Plant Physiol 21(2-3):24-32

Little R (1988) Plant soil interaction at low $\mathrm{pH}$ : problem solving genetic approach. Commun Soil Sci Plant Anal 19:1239-1257

López-Marín HD, Rao IM, Blair MW (2009) Quantitative trait loci for aluminum toxicity resistance in common bean (Phaseolus vulgaris L.). Theor Appl Genet 119:449-458

Lynch J (1995) Update on root biology: root architecture and plant productivity. Plant Physiol 109:7-13

Manrique G, Rao IM, Beebe S (2006) Identification of aluminum resistant common bean genotypes using a hydroponic screening method. Paper presented at the 18th world congress of soil science, Philadelphia, USA, 9-15 Jul 2006 
Marschner H (1991) Mechanisms of adaptation of plants to acid soils. Plant Soil 134:1-20

Massot N, Llugany M, Poschenrieder Ch, Barcelo J (1999) Callose production production as indicator of aluminum toxicity in bean cultivars. J Plant Nutr 22:1-10

Mossor-Pietraszewska T (2001) Effect of aluminum on plant growth and metabolism. Acta Biolochim Pol 48(3):673-686

Muñoz-Perea CG, Terán H, Allen RG, Wright JL, Westermann DT, Singh SP (2006) Selection for drought resistance in dry bean landraces and cultivars. Crop Sci 46:2111-2120

Narasimhamoorthy B, Blancaflor EB, Bouton JH, Payton ME, Sledge MK (2007) A comparison of hydroponics, soil, and root staining methods for evaluation of aluminum tolerance in Medicago truncatula (Barrel medic) germplasm. Crop Sci 47:321-328

Pandey S, Ceballos H, Mgnavaca R, Bahia Filho AFC, DuqueVargas J, Vinasco LE (1994) Genetics of tolerance to soil acidity in tropical maize. Crop Sci 34:1511-1514

Polanía J, Rao IM, Beebe S, García R (2009) Desarrollo y distribución de raices bajo estrés por sequía en frijol común (Phaseolus vulgaris L.) en un sistema de tubos con suelo. Agron Colomb 27:25-32

Rangel AF, Mobin M, Rao IM, Horst WJ (2005) Proton toxicity interferes with the screening of common bean (Phaseolus vulgaris L.) genotypes for aluminum resistance in nutrient solution. J Plant Nutr Soil Sci 168:607-616

Rangel AF, Rao IM, Horst WJ (2007) Spatial aluminum sensitivity of root apices of two common bean (Phaseolus vulgaris L.) genotypes with contrasting aluminum resistance. J Exp Bot 58:3896-3904

Rangel AF, Rao IM, Horst WJ (2009) Intracellular distribution and binding state of aluminum in root apices of two common bean (Phaseolus vulgaris L.) genotypes in relation to Al toxicity. Physiol Plant 135:162-173

Rangel AF, Rao IM, Braum HP, Horst WJ (2010) Aluminum resistance in common bean (Phaseolus vulgaris L.) involves induction and maintenance of citrate exudation from root apices. Physiol Plant 138:176-190

Rao IM (2001) Role of physiology in improving crop adaptation to abiotic stresses in the tropics: the case of common bean and tropical forages. In: Pessarakli M (ed) Handbook of plant and crop physiology. Marcel Dekker, Inc., New York, pp 583-613

Rao IM, Beebe S, Ricaurte J, Teran H, Singh S (2004) Common bean (Phaseolus vulgaris L.) genotypes tolerant to aluminum-toxic soils in the tropics. In: Matsumoto $\mathrm{H}$, Nanzyo M, Inubushi K, Yamamoto Y, Koyama H, Saigusa M, Osaki M, Sakurai K (eds) Proceedings of the 6th international symposium on plant-soil interactions at low $\mathrm{pH}$. Japanese Society of Soil Science and Plant Nutrition (JSSSPN), pp 272-273

Rao IM, Beebe S, Ricaurte J, Cajiao C, Polania J, Garcia R (2007) Phenotypic evaluation of drought resistance in advanced lines of common bean (Phaseolus vulgaris L.). Paper presented at ASA-CSSA-SSSA international annual meeting, New Orleans, LA, USA, 4-8 Nov 2007

Ryan PR, DiTomaso JM, Kochian LV (1993) Aluminum toxicity in roots: an investigation of spatial sensitivity and the role of the cap. J Exp Bot 44:437-446

Ryser P, Lambers H (1995) Root and leaf attributes accounting for the performance of fast- and slow-growing grasses at different nutrient supply. Plant Soil 170:251-265

Sapra VT, Mebrahtu T, Mugwira LM (1982) Soybean germplasm and cultivar aluminum tolerance in nutrient solution and Bladen clay loam soil. Agron J 74:687-690

Silva IR, Smyth TJ, Israel DW, Rufty TW (2001) Altered aluminum inhibition of soybean root elongation in the presence of magnesium. Plant Soil 230:223-230

Singh SP, White JW (1988) Breeding common beans for adaptation to drought conditions. In: White JW, Hoogenboom F, Ibarra F, Singh SP (eds) Research on drought tolerance in common bean. Working Document No. 41, Bean Program. CIAT, Cali, pp 261-285

Spehar CR (1994) Aluminum tolerance of soya bean genotypes in short term experiments. Euphytica 76:73-80

Sponchiado BN, White JW, Castillo JA, Jones PG (1989) Root growth of four common bean cultivars in relation to drought tolerance in environments with contrasting soil types. Exp Agric 25:249-257

Subbarao GV, Johansen C, Slinkard AE, Nageswara Rao RC, Saxena NP, Chauhan YS (1995) Strategies for improving drought tolerance in grain legumes. Crit Rev Plant Sci 14:469-523

Thung M, Rao IM (1999) Integrated management of abiotic stresses. In: Singh SP (ed) Common bean improvement in the twenty-first century. Kluwer Academic Publishers, Dordrecht, pp 331-370

Urrea-Gómez R, Ceballos H, Pandey S, Bahía Filho AFC, León LA (1996) A greenhouse screening technique for acid soil tolerance in maize. Agron J 88:806-812

Villagarcia MR, Carter TE Jr, Rufty TW, Niewoehner AS, Jennette MW, Arrellano C (2001) Genotypic ranking for aluminum tolerance of soybean roots grown in hydroponics and sand culture. Crop Sci 41:1499-1507

White JW, Castillo JA (1988) Studies at CIAT on mechanisms of drought tolerance in common bean. In: White JW, Hoogenboom G, Ibarra F, Singh SP (eds) Research on drought tolerance in common bean. Centro Internacional de Agricultura Tropical, Cali, pp 146-151

Wortmann CS, Kirkby RA, Eledu CA, Allan DJ (1998) Atlas of common bean (Phaseolus vulgaris L.) production in Africa. CIAT publication no. 297. CIAT, Cali

Yang Z, Eticha D, Rao IM, Horst WJ (2010) Alteration of cellwall porosity is involved in osmotic stress-induced enhancement of aluminum resistance in common bean (Phaseolus vulgaris L.). J Exp Bot 61:3245-3258 